Brazilian Journal

of Chemical

Engineering

\title{
THERMOPHILIC BIOMETHANE PRODUCTION BY VINASSE IN AN AnSBBR: START-UP STRATEGY AND PERFORMANCE OPTIMIZATION
}

\author{
Juliane N. de Albuquerque', Marcela R. Orellana², \\ Suzana M. Ratusznei ${ }^{2}$ \& José A. D. Rodrigues ${ }^{2 *}$ \\ ${ }^{1}$ Universidade de São Paulo, Escola de Engenharia de São Carlos, São Carlos, SP, Brasil. ORCID: 0000-0002-1704-8313 \\ ${ }^{2}$ Instituto Mauá de Tecnologia, Escola de Engenharia Mauá, São Caetano do Sul, SP, Brasil. ORCID: 0000-0003-2401-2754; \\ E-mail: rodrigues@maua.br - ORCID: 0000-0003-0731-8604
}

(Submitted: November 29, 2017 ; Revised: October 27, 2018 ; Accepted: November 19, 2018)

\begin{abstract}
Thermophilic anaerobic digestion treatment of industrial wastewater generated at high temperatures can be used as an alternative for environmental pollution control and bioenergy production. Therefore, this study investigated thermophilic anaerobic reactors containing immobilized biomass (AnSBBR) to treat vinasse for methane production, in batch and fed-batch mode, in a three-step approach. In Step I (batch), the biomass was properly adapted to the thermophilic condition $\left(55^{\circ} \mathrm{C}\right)$ with a feed containing vinasse plus molasses as a cosubstrate. In Step II (batch), the applied volumetric organic load (AVOL) was increased and resulted in a methane molar productivity of $304 \mathrm{molCH}_{4} \cdot \mathrm{m}^{-3} \cdot \mathrm{d}^{-1}$ at an AVOL of $25.9 \mathrm{gCOD} \cdot \mathrm{L}^{-1} \cdot \mathrm{d}^{-1}$ and a yield of methane per removed organic matter near $331 \mathrm{NmL}^{-\mathrm{CH}_{4}} \cdot \mathrm{gCOD}^{-1}$. In Step III, a fed-batch strategy was employed at an AVOL of 25.1 gCOD. $\mathrm{L}^{-1} \cdot \mathrm{d}^{-1}$ and achieved an optimum methane productivity of $352 \mathrm{molCH}_{4} \cdot \mathrm{m}^{-3} \cdot \mathrm{d}^{-1}$ with COD and carbohydrate removal efficiencies of approximately $80 \%$ and $90 \%$, respectively. A kinetic model fitted to the experimental data allowed better understanding of the anaerobic metabolic reactions. Finally, the results obtained demonstrated that a thermophilic AnSBBR is an efficient technological alternative for methane production through vinasse digestion. Keywords: Methane; Feed time; Influent concentration; Anaerobic reactor.
\end{abstract}

\section{INTRODUCTION}

Environmental problems inherent in the exploration and use of fossil fuels have stimulated the development of biofuels, such as ethanol, which can be obtained from different sources (Wilkie et al, 2000; Gamboa et al., 2011). In Brazil ethanol, of which the production exceeded 30 billion liters in 2016 (CONAB, 2017), is obtained mainly from sugarcane, as climate and territorial extension facilitate cultivation of this crop. An inherent problem faced by ethanol and sugar mills is the destination of the by-product vinasse, which is generated at a ratio of $12-15$ liters per liter of produced ethanol. The alternative most adopted for vinasse destination is soil fertigation, i.e., vinasse is incorporated into the water used for irrigation, which in the long run may cause changes in the physical properties of the soil.

This problem, allied to the growing volume of generated vinasse, has stimulated the search for technologies that reduce the polluting potential of vinasse without losing its nutritive properties. One of these technologies is the anaerobic reactor operated in batch and fed-batch mode (AnSBBR) which has presented promising results regarding environmental compliance and energy recovery from wastewaters. These reactors are indicated for wastewaters with high organic load and nutritive characteristics, such

\footnotetext{
* Corresponding author: José A. D. Rodrigues - E-mail: rodrigues@maua.br
} 
as vinasse, because nutrient properties are conserved even after treatment, which enables further use as fertilizer (Vlissidis and Zouboulis, 1993; Barros et al., 2016).

In the literature, few studies have focused on the thermophilic treatment of vinasse in anaerobic reactors and the settings that offer the best performance and operational stability have not been well defined yet. Ribas et al. (2009) reported $70 \%$ COD removal and a 70 $\%$ methane fraction in biogas by a mesophilic AnSBBR reactor for sugar cane-vinasse treatment. Almeida et al. (2017) studied the same reactor configuration and reported an increase in COD removal efficiency (97\%) and methane productivity $\left(123 \mathrm{molCH}_{4} \cdot \mathrm{m}^{-3} \cdot \mathrm{d}^{-1}\right)$ with increasing applied volumetric organic load (AVOL) $\left(1.1-10.1\right.$ gCOD. $\left.\mathrm{L}^{-1} \cdot \mathrm{d}^{-1}\right)$. It should be mentioned that a major challenge in the vinasse anaerobic treatment is temperature. During the distillation process the liquid achieves temperatures near $90{ }^{\circ} \mathrm{C}$, which reduces to $60{ }^{\circ} \mathrm{C}$ on the way to the treatment system due to heat losses. To render thermophilic treatment practicable for this wastewater, cooling should be used to apply biologic treatment under mesophilic conditions (Ribas et al., 2009).

Within this context, this investigation aimed to study the biotechnological viability of an anaerobic reactor operating in batch and fed-batch mode with mechanical stirring and immobilized biomass (AnSBBR) under thermophilic conditions treating vinasse for methane production. To this end, an assessment was made of the effect of the thermophilic biomass adaptation strategy on vinasse, as well as of the effect of increasing organic load in batch and fed-batch mode on performance indicators related to operational stability, organic matter removal, yield (methane generated per substrate consumed) and biogas productivity/composition.

\section{MATERIALS AND METHODS}

\section{AnSBBR}

The anaerobic sequencing batch biofilm reactor containing immobilized biomass used in this work was the same as that of Albanez et al. (2016). The AnSBBR (Figure 1) was operated in batch and fed-batch mode, at $55^{\circ} \mathrm{C}$, controlled by a water jacket, of which the temperature was regulated by an ultrathermostatic bath. Stirring was set at $100 \mathrm{rpm}$ and the cycle length was $8 \mathrm{~h}$.

\section{Inoculum, inert support and feed composition}

The inoculum, taken from a thermophilic UASB reactor treating vinasse from an ethanol plant, contained

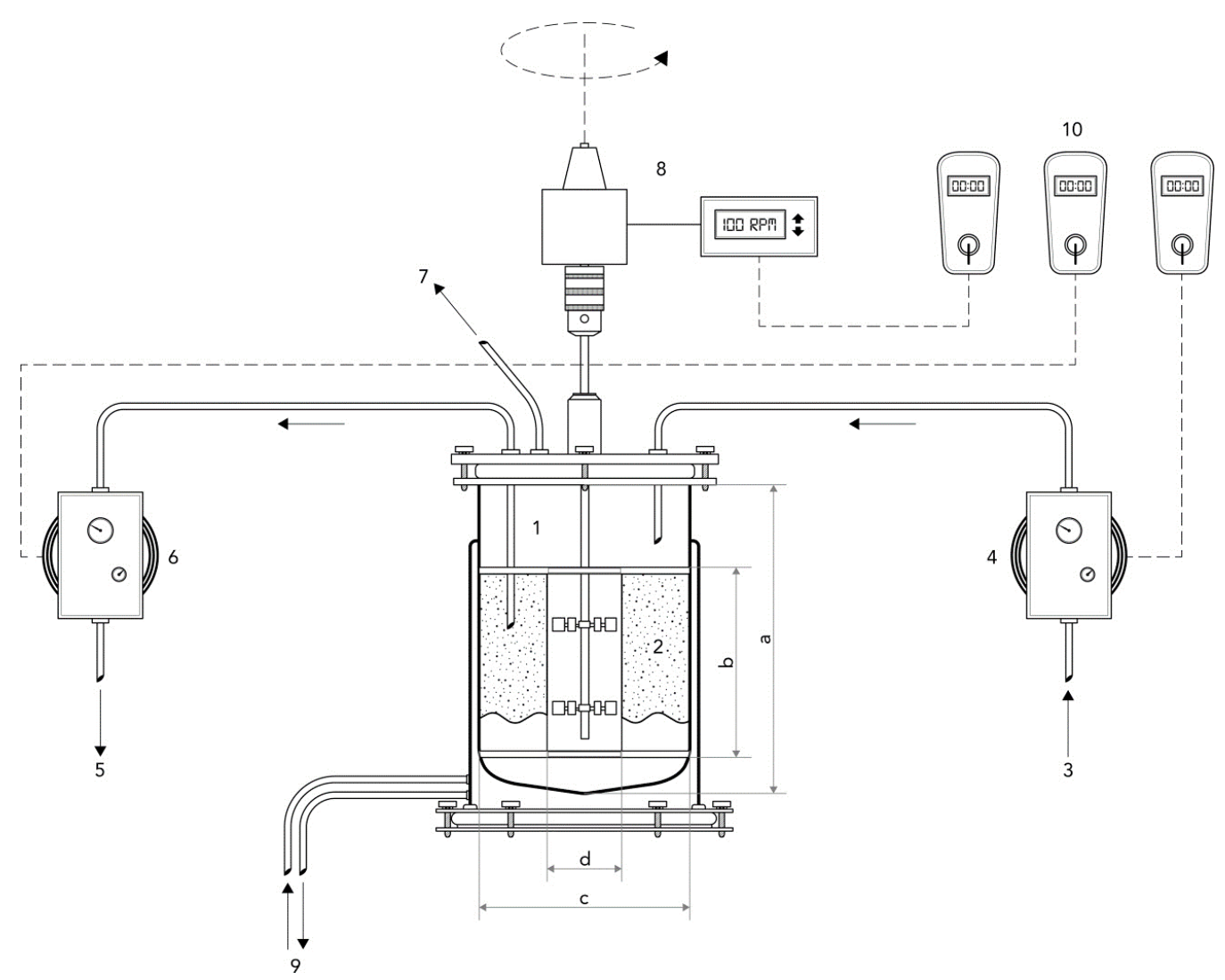

Figure 1. Scheme of the reactor used in this study. [ (a) Reactor BIOFLO III (New Brunswick Scientific Co.) with 6 L capacity; 2 - basket containing support material with immobilized biomass $(\mathrm{c}=18.0 \mathrm{~cm} ; \mathrm{d}=7.0 \mathrm{~cm}) ; 3-\mathrm{Influent}$; 4 - Feed pump; 5 - Effluent; 6 - Discharge pump; 7 - Biogas outlet; 8 - Mechanical agitation; 9 - Temperature control system (ultrathermostatic bath)]. Adapted from Albanez et al. (2016) 
17 g. $\mathrm{L}^{-1}$ of total volatile solids. The inert support used to immobilize the biomass consisted of polyurethane foam cubes ( $1 \mathrm{~cm}$ edges). The immobilization process was performed according to the method proposed by Zaiat et al. (1994).

The molasses and vinasse used to prepare the wastewater were obtained from a bioethanol plant and they were stored at $-4{ }^{\circ} \mathrm{C}$. The vinasse presented 27.6 \pm 4.6 gCOD.L ${ }^{-1}\left(6.2 \pm 1.8\right.$ gCarbohydrate. $\left.\mathrm{L}^{-1}\right)$ and $\mathrm{pH}$ 4.5 , whereas the molasses presented an average of 1.2 gCOD.L ${ }^{-1}$.

According to each experimental stage, the wastewater was diluted with water from the public supply system and supplemented with urea (5.8

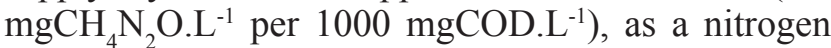
source, and sodium bicarbonate $(200$ - $100 \mathrm{mg}$ $\mathrm{NaHCO}_{3} \cdot \mathrm{L}^{-1}$ per $1000 \mathrm{mgCOD} . \mathrm{L}^{-1}$ ) as a buffering agent. These values were proportionally modified according to the effluent concentration.

\section{Physical-chemical analyses}

Reactor monitoring was carried out for influent and effluent samples at least 4 times a week, except for the solids analyses which were carried out twice. The reactor performance was monitored as Chemical Oxygen Demand (COD - $\mathrm{C}_{\mathrm{MO}}$ ) and Carbohydrate $\left(\mathrm{C}_{\mathrm{C}}\right)$ in filtered samples $\left(\mathrm{C}_{\mathrm{MOF}}\right.$ and $\mathrm{C}_{\mathrm{CF}}$ - filtered on a membrane of micro glass fiber with nominal pore diameter of $0.45 \mu \mathrm{m})$. The system stability was monitored by measuring $\mathrm{pH}$, bicarbonate alkalinity (BA), total volatile acids (TVA), total solids (TS), total volatile solids (TVS), total suspended solids (TSS) and volatile suspended solids (VSS). The analyses were performed according to Standard Methods for the Examination of Water and Wastewater (APHA, 1995), Ripley et al. (1986) for alkalinity determination, and Dubois et al. (1956) for carbohydrate determination.

The intermediate compounds analyses of the anaerobic metabolism (ethanol and organic acids: acetic, propionic, butyric/isobutyric, valeric/isovaleric and caproic; limit of detection of $0.5 \mathrm{mmol} . \mathrm{L}^{-1}$ ) was performed via gas chromatography (head-space) with external standard (iso-butanol and crotonic acid) using an Agilent ${ }^{\circledR} 7890$ chromatograph equipped with a flame ionization detector and an HPInnowax column. The biogas composition (carbon dioxide - $\mathrm{CO}_{2}$ and methane $-\mathrm{CH}_{4}$; limit of detection of $0.1 \mathrm{mmol.L}-1$ ) was also performed by gas chromatography using the same chromatograph but equipped with a thermal conductivity detector and GS-Carbonplot column. These methods are described in Almeida et al. (2017).

\section{Stability and performance indicators}

The stability and performance indicators used are described in Almeida et al. (2017): removal efficiency of total organic matter for soluble samples $\left(\varepsilon_{\mathrm{F}}\right)$, applied volumetric organic load (AVOL), removed volumetric organic load (RVOL), molar (MPr) and volumetric (VPr) productivity, specific molar (SMPr) and specific volumetric (SVPr) productivity and methane yield per consumed load $\left(\mathrm{Y}_{\mathrm{MO}}\right)$.

The biogas volume produced during a cycle $\left(\mathrm{V}_{\mathrm{G}}\right)$ was measured using a Ritter $^{\circledR}$ MilligasCounter. The accumulated volumes of biogas at each point were calculated by Equation (1) for the fed-batch mode condition $\left(\mathrm{V}_{\mathrm{Gi}-\mathrm{BA}}\right)$, in which the quantification was corrected because the biogas production occurred concomitant with the effluent feeding to the reactor and by Equation (2) for the batch mode condition $\left(\mathrm{V}_{\mathrm{Gi}-\mathrm{B}}\right)$, using the volume recorded by the biogas meter $\left(\mathrm{V}_{\mathrm{M}-\mathrm{i}}^{\mathrm{G}}\right)$, the biogas profile point number $\left(\mathrm{N}_{\mathrm{i}}\right)$, the total number of profile points during the fed batch $\left(\mathrm{N}_{\mathrm{t}-\mathrm{BA}}\right)$ and effluent volume fed during the cycle $\left(\mathrm{V}_{\mathrm{A}}\right)$.

$\mathrm{V}_{\mathrm{Gi}-\mathrm{BA}}=\mathrm{V}_{\mathrm{M}-\mathrm{i}}-\frac{\mathrm{N}_{\mathrm{i}}}{\mathrm{N}_{\mathrm{t}-\mathrm{BA}}} \mathrm{V}_{\mathrm{A}}$

$\mathrm{V}_{\mathrm{Gi}-\mathrm{B}}=\mathrm{V}_{\mathrm{M}-\mathrm{i}}-\mathrm{V}_{\mathrm{A}}$

The conversion of the biogas volume at standard temperature and pressure conditions was calculated according to the general gas law by Equation (3) and the number of moles of generated methane $\left(\mathrm{n}_{\mathrm{CH} 4}\right.$ in mmol) was calculated by Equation (4), using volume $\left(\mathrm{V}_{\mathrm{N}}\right)$ at STP, the biogas volume to be converted $\left(\mathrm{V}_{\mathrm{i}}\right.$ $\mathrm{V}_{\mathrm{Gi}-\mathrm{BA}}$ or $\mathrm{V}_{\mathrm{Gi}-\mathrm{B}}$ ), air pressure at the measurement point $\left(\mathrm{P}_{\mathrm{A}}\right)$, partial pressure of water vapor $\left(\mathrm{P}_{\mathrm{V}}\right)$, pressure of the liquid column above the measuring chamber $\left(\mathrm{P}_{\mathrm{L}}=\right.$ 2 mbar), normal pressure ( $\left.\mathrm{P}_{\mathrm{N}}=1013.25 \mathrm{mbar}\right)$, normal temperature $\left(\mathrm{T}_{\mathrm{N}}=273.15 \mathrm{~K}\right)$, temperature inside the reactor $\left(\mathrm{T}_{\mathrm{a}}=55^{\circ} \mathrm{C}\right)$, pressure $(\mathrm{P}=1 \mathrm{~atm})$ and Clapeyron constant $\left(\mathrm{R}=0.082 \mathrm{~atm} \cdot \mathrm{L} \cdot \mathrm{K}^{-1} \cdot \mathrm{mol}^{-1}\right)$.

$V_{N}=V_{i} \frac{\left(P_{A}-P_{V}+P_{L}\right)}{P_{N}} \frac{T_{N}}{T_{a}}$

$\mathrm{n}_{\mathrm{CH}_{4}}=\frac{\text { P. } \mathrm{V}_{\mathrm{N}}}{\text { R. } \mathrm{T}_{\mathrm{N}}}$

At the end of each experimental condition, the reactor was discharged and the residual volume $\left(\mathrm{V}_{\mathrm{R}}\right)$ of liquid medium in the reactor was measured. The inert support holding immobilized biomass was weighed and a sample of this material (foam and biomass) was collected and quantified. It should be mentioned that there is no guarantee that TVS consists only of biomass, due to the complex composition of the medium and the measurements are hence only an estimate. Next, the foam was washed with distilled water, which separated the solid (inert support) and the liquid (immobilized biomass) phases. TS was measured in the solid phase, 
and TS $\left(\mathrm{M}_{\mathrm{A}-\mathrm{TS}}\right)$ and TVS $\left(\mathrm{M}_{\mathrm{A}-\mathrm{TVS}}\right)$ were measured in the liquid phase. The total amount of biomass in the reactor $\left(\mathrm{M}_{\mathrm{TVS}}\right)$ was calculated by Equation (5), where $\left(\mathrm{M}_{\mathrm{T}-\mathrm{SI}+\mathrm{B}}\right)$ is total biomass and foam inside the reactor, $\left(\mathrm{M}_{\mathrm{A}-\mathrm{TVS}}\right)$ is the mass of total volatile solids in the sample and $\left(\mathrm{M}_{\mathrm{A}-\mathrm{SI}+\mathrm{B}}\right)$ is the sample collected from the inert material containing immobilized biomass.

The relation between the amount of biomass and liquid medium in the reactor $\left(\mathrm{C}_{\mathrm{x}}\right)$ was calculated by Equation (6), where $V_{R}$ is the liquid volume in the reactor, and the relation between the amount of biomass and inert support in the reactor $\left(\mathrm{C}_{\mathrm{X}},\right)_{\text {was }}$ calculated by Equation (7), where $\mathrm{M}_{\mathrm{A}-\mathrm{SI}}$ is the amount of inert support available for immobilization.

$$
\begin{aligned}
& \mathrm{M}_{\mathrm{TVS}}=\frac{\mathrm{M}_{\mathrm{A}-\mathrm{TVS}} \cdot \mathrm{M}_{\mathrm{T}-\mathrm{SI}+\mathrm{B}}}{\mathrm{M}_{\mathrm{A}-\mathrm{SI}+\mathrm{B}}} \\
& \mathrm{C}_{\mathrm{X}}=\frac{\mathrm{M}_{\mathrm{TVS}}}{\mathrm{V}_{\mathrm{R}}} \\
& \mathrm{C}_{\mathrm{X}^{\prime}}=\frac{\mathrm{M}_{\mathrm{A}-\mathrm{TVS}}}{\mathrm{M}_{\mathrm{A}-\mathrm{SI}}}
\end{aligned}
$$

\section{Experimental Procedure}

The operating procedure of the reactor was as follows: a) feeding - $1.0 \mathrm{~L}$ in $10 \mathrm{~min}$ in batch mode and $240 \mathrm{~min}$ in fed-batch mode; b) agitation and reaction (for fed-batch mode the feed time was included); c) discharge - $1.0 \mathrm{~L}$ in $10 \mathrm{~min}$, guaranteeing a residual volume $\left(\mathrm{V}_{\mathrm{R}}\right)$ of $1.3 \mathrm{~L}$ of the total liquid volume inside the reactor $(2.3 \mathrm{~L})$. In all experiments the AnSBBR was operated at $55^{\circ} \mathrm{C}$, stirring was set at $100 \mathrm{rpm}$ with a cycle length of $8 \mathrm{~h}$. These values were adopted from previous investigations of methane production using the reactor (Almeida et al., 2017; Albanez et al., 2016; Silva et al., 2013; Lovato et al., 2012; Bezerra et al., 2011; Selma et al., 2010; Michelan et al., 2009).

The reactor operation was performed in three steps:

- $\quad$ Step I (duration of 40 days): The reactor was operated in batch mode and the assays were carried out in two phases to implement a reactor start-up strategy that allows acclimatization of the biomass. Phase 1: wastewater was molasses-based because of its high biodegradability. The influent concentration and temperature were increased from $1000 \mathrm{mgCOD}^{-1}$ to $5000 \mathrm{mgCOD} . \mathrm{L}^{-1}\left(1.5-7.0 \mathrm{gCOD} \cdot \mathrm{L}^{-1} \cdot \mathrm{d}^{-1}\right)$ and from 35 ${ }^{\circ} \mathrm{C}$ to $55^{\circ} \mathrm{C}$, respectively. They were modified as soon as the monitored parameters achieved stability. Phase 2: concentration (5000 $\mathrm{mgCOD} . \mathrm{L}^{-1}$ ) and temperature $\left(55^{\circ} \mathrm{C}\right)$ were kept constant and wastewater composition was altered by adding vinasse (from $100 \%$ molasses to $100 \%$ vinasse).

- $\quad$ Step II (duration of 110 days): The reactor was operated in batch mode, at $55^{\circ} \mathrm{C}$, with vinasse- based wastewater, using different volumetric organic loads by varying the influent concentration from 5000 mgCOD.L ${ }^{-1}$ to $20000 \mathrm{mgCOD} . \mathrm{L}^{-1}$ (AVOL 6.5 to 25.9 gCOD.L $\left.\mathrm{L}^{-1} \cdot \mathrm{d}^{-1}\right)$;

- $\quad$ Step III (duration of 25 days): The reactor was operated at $55^{\circ} \mathrm{C}$, the wastewater was vinasse-based, influent concentration was $20000 \mathrm{mgCOD}^{-1}$ (25.1 gCOD. $\left.\mathrm{L}^{-1} \cdot \mathrm{d}^{-1}\right)$, and the feeding strategy was modified to fed-batch mode with feeding time of $240 \mathrm{~min}$.

The mean values of the monitored variables were calculated for each experimental condition as follows: (i) 14 samples for each of the operational variables: temperature, liquid volume (fed per cycle), substrate (COD and Carbohydrate), bicarbonate alkalinity, total volatile acids, biogas production and composition $\left(\mathrm{CH}_{4} /\right.$ $\mathrm{CO}_{2}$ ) resulting in a maximum standard deviation of $6 \%$; (ii) 6 samples for each of the operational variables: influent/effluent solids (TS, TSS, VSS) resulting in a maximum standard deviation of $12 \%$; (iii) 2 samples for each of the operational variables: (HAc, $\mathrm{HPr}, \mathrm{HBu}$, $\mathrm{HVa}$ ) and biomass inside the reactor $(\mathrm{Cx})$, resulting in a maximum standard deviation of $8 \%$.

When reactor stability was achieved under the monitored experimental conditions, a time profile was taken along the operating cycle regarding soluble organic matter concentrations (in the form of COD and carbohydrate), bicarbonate alkalinity, $\mathrm{pH}$, total volatile acids, intermediate metabolites and biogas (composition and production). Samples were taken every 30 to $60 \mathrm{~min}$, in a way to not exceed $200 \mathrm{~mL}$ of total collected volume. In this way, it was possible to get a better understanding of the metabolic routes along the cycle. Thus, a new experimental condition was implemented by changing the influent concentration or the feeding strategy.

\section{Kinetic metabolic model}

The kinetic model for the metabolic pathways proposed in this investigation was adapted from Bagley and Brodkorb (1999), Rodrigues et al. (2004) and Lovato et al. (2016). The model admits a simplified metabolic pathway in eleven steps (Equations 8 to 18). In the first five parallel steps (hydrolysis and acidogenesis), the substrate (S), sucrose, was converted to acetic acid (HAc), propionic acid (HPr), butyric acid $(\mathrm{HBu})$, valeric acid (HVa) and ethanol (EtOH). In the following four steps (acetogenesis), propionic acid, butyric acid, valeric acid and ethanol were consumed to acetic acid, shorter chain acids and hydrogen $(\mathrm{H})$. In the next two independent steps (methanogenesis), methane (M) was produced by acetoclastic and hydrogenotrophic routes. At all stages, conversion reactions were considered to be first order.

Hydrolysis and acidogenesis

$$
\mathrm{C}_{12} \mathrm{H}_{22} \mathrm{O}_{11}+5 \mathrm{H}_{2} \mathrm{O} \stackrel{\mathrm{k}_{1}}{\rightarrow} 4 \mathrm{CH}_{3} \mathrm{COOH}+4 \mathrm{CO}_{2}+8 \mathrm{H}_{2}
$$


$\mathrm{C}_{12} \mathrm{H}_{22} \mathrm{O}_{11}+4 \mathrm{H}_{2} \stackrel{\mathrm{k}_{2}}{\rightarrow} 4 \mathrm{CH}_{3} \mathrm{CH}_{2} \mathrm{COOH}+3 \mathrm{H}_{2} \mathrm{O}$

$\mathrm{C}_{12} \mathrm{H}_{22} \mathrm{O}_{11}+1 \mathrm{H}_{2} \mathrm{O} \stackrel{\mathrm{k}_{3}}{\rightarrow} 2 \mathrm{CH}_{3} \mathrm{CH}_{2} \mathrm{CH}_{2} \mathrm{COOH}+4 \mathrm{CO}_{2}+4 \mathrm{H}_{2}$

$8 \mathrm{C}_{12} \mathrm{H}_{22} \mathrm{O}_{11} \stackrel{k_{3}}{\rightarrow} 13 \mathrm{CH}_{3} \mathrm{CH}_{2} \mathrm{CH}_{2} \mathrm{CH}_{2} \mathrm{COOH}+31 \mathrm{CO}_{2}+23 \mathrm{H}_{2}$

$\mathrm{C}_{12} \mathrm{H}_{22} \mathrm{O}_{11}+1 \mathrm{H}_{2} \mathrm{O} \stackrel{\mathrm{k}_{5}}{\rightarrow} 4 \mathrm{CH}_{3} \mathrm{CH}_{2} \mathrm{OH}+4 \mathrm{CO}_{2}$

\section{Acetogenesis}

$\mathrm{CH}_{3} \mathrm{CH}_{2} \mathrm{COOH}+2 \mathrm{H}_{2} \mathrm{O} \stackrel{\mathrm{k}_{6}}{\rightarrow} \mathrm{CH}_{3} \mathrm{COOH}+\mathrm{CO}_{2}+3 \mathrm{H}_{2}$

$\mathrm{CH}_{3} \mathrm{CH}_{2} \mathrm{CH}_{2} \mathrm{COOH}+2 \mathrm{H}_{2} \mathrm{O} \stackrel{\mathrm{k}_{7}}{\rightarrow} \mathrm{CH}_{3} \mathrm{CH}_{2} \mathrm{COOH}+\mathrm{CO}_{2}+3 \mathrm{H}_{2}$

$\mathrm{CH}_{3} \mathrm{CH}_{2} \mathrm{CH}_{2} \mathrm{CH}_{2} \mathrm{COOH}+2 \mathrm{H}_{2} \mathrm{O} \stackrel{\mathrm{k}_{8}}{\rightarrow} \mathrm{CH}_{3} \mathrm{CH}_{2} \mathrm{CH}_{2} \mathrm{COOH}+\mathrm{CO}_{2}+3 \mathrm{H}_{2}$

$\mathrm{CH}_{3} \mathrm{CH}_{2} \mathrm{OH}+\mathrm{H}_{2} \mathrm{O} \stackrel{\mathrm{k}_{9}}{\rightarrow} \mathrm{CH}_{3} \mathrm{COOH}+2 \mathrm{H}_{2}$

\section{Methanogenesis}

$\mathrm{CH}_{3} \mathrm{COOH} \stackrel{\mathrm{k}_{10}}{\rightarrow} \mathrm{CH}_{4}+\mathrm{CO}_{2}$

$4 \mathrm{H}_{2}+\mathrm{CO}_{2} \stackrel{\mathrm{k}_{11}}{\rightarrow} \mathrm{CH}_{4}+2 \mathrm{H}_{2} \mathrm{O}$

Equations (19) to (26) present the reaction rate equations for consumption of substrate $\left(\mathrm{r}_{\mathrm{S}}\right)$, consumption and/or formation of acetic acid $\left(\mathrm{r}_{\mathrm{HAc}}\right)$, propionic acid $\left(\mathrm{r}_{\mathrm{HPr}}\right)$, butyric acid $\left(\mathrm{r}_{\mathrm{HBu}}\right)$, valeric acid $\left(\mathrm{r}_{\mathrm{HVa}}\right)$, ethanol $\left(\mathrm{r}_{\mathrm{ETOH}}\right)$, hydrogen $\left(\mathrm{r}_{\mathrm{H}}\right)$, and methane $\left(\mathrm{r}_{\mathrm{M}}\right)$, respectively, containing apparent kinetic parameters associated with substrate consumption, volatile acids formation/consumption and methane formation. The kinetic parameter " $\mathrm{k}$ " refers to reaction rate constant, indicating a relation with the time required for the compound concentration ( $\mathrm{S}, \mathrm{HAc}, \mathrm{HPr}, \mathrm{HBu}, \mathrm{HVa}$, EtOH, $\mathrm{H}$ and $\mathrm{M}$ ) to reach a residual value according to the kinetic model hypothesis. Indices " 1 to 11 " refer to the reactions and indices " $\mathrm{S}, \mathrm{HAc}, \mathrm{HPr}, \mathrm{HBu}, \mathrm{HVa}$, $\mathrm{EtOH}, \mathrm{H}$ and M" refer to the experimental values used to calculate these parameters.

$$
\begin{aligned}
& \mathrm{r}_{\mathrm{S}}=-\left(\mathrm{k}_{1 \mathrm{~S}}+\mathrm{k}_{2 \mathrm{~S}}+\mathrm{k}_{3 \mathrm{~S}}+\mathrm{k}_{4 \mathrm{~S}}+\mathrm{k}_{5 \mathrm{~S}}\right) \cdot \mathrm{C}_{\mathrm{S}}=-\mathrm{k}_{1 \mathrm{~S}} \cdot \mathrm{C}_{\mathrm{S}} \\
& \mathrm{r}_{\mathrm{HAc}}=\mathrm{k}_{1 \mathrm{HAc}} \cdot \mathrm{C}_{\mathrm{S}}+\mathrm{k}_{6 \mathrm{HAc}} \cdot \mathrm{C}_{\mathrm{HPr}}+\mathrm{k}_{9 \mathrm{HAc}} \cdot \mathrm{C}_{\mathrm{EtOH}}-\mathrm{k}_{10 \mathrm{HAc}} \cdot \mathrm{C}_{\mathrm{HAc}} \\
& \mathrm{r}_{\mathrm{HPr}}=\mathrm{k}_{2 \mathrm{HPr}} \cdot \mathrm{C}_{\mathrm{S}}-\mathrm{k}_{6 \mathrm{HPr}} \cdot \mathrm{C}_{\mathrm{HPr}}+\mathrm{k}_{7 \mathrm{HPr}} \cdot \mathrm{C}_{\mathrm{HBu}}
\end{aligned}
$$

$$
\begin{aligned}
& \mathrm{r}_{\mathrm{HBu}}=\mathrm{k}_{3 \mathrm{HBu}} \cdot \mathrm{C}_{\mathrm{S}}-\mathrm{k}_{7 \mathrm{HBu}} \cdot \mathrm{C}_{\mathrm{HBu}}+\mathrm{k}_{8 \mathrm{HBu}} \cdot \mathrm{C}_{\mathrm{HVa}} \\
& \mathrm{r}_{\mathrm{HVa}}=\mathrm{k}_{4 \mathrm{HVa}} \cdot \mathrm{C}_{\mathrm{S}}-\mathrm{k}_{8 \mathrm{HVa}} \cdot \mathrm{C}_{\mathrm{HVa}} \\
& \mathrm{r}_{\mathrm{EtOH}}=\mathrm{k}_{5 \mathrm{EtOH}} \cdot \mathrm{C}_{\mathrm{S}}-\mathrm{k}_{9 \mathrm{HAc}} \cdot \mathrm{C}_{\mathrm{EtOH}} \\
& \mathrm{r}_{\mathrm{H}}=\mathrm{k}_{1 \mathrm{H}} \cdot \mathrm{C}_{\mathrm{S}}-\mathrm{k}_{2 \mathrm{H}} \cdot \mathrm{C}_{\mathrm{S}}+\mathrm{k}_{3 \mathrm{H}} \cdot \mathrm{C}_{\mathrm{S}}+\mathrm{k}_{4 \mathrm{H}} \cdot \mathrm{C}_{\mathrm{S}}+\mathrm{k}_{6 \mathrm{H}} \cdot \mathrm{C}_{\mathrm{HPr}}+ \\
& +\mathrm{k}_{7 \mathrm{H}} \cdot \mathrm{C}_{\mathrm{HBu}}+\mathrm{k}_{8 \mathrm{H}} \cdot \mathrm{C}_{\mathrm{HVa}}+\mathrm{k}_{9 \mathrm{H}} \cdot \mathrm{C}_{\mathrm{EtOH}}-\mathrm{k}_{11 \mathrm{H}} \cdot \mathrm{C}_{\mathrm{H}} \\
& \mathrm{r}_{\mathrm{M}}=\mathrm{k}_{10 \mathrm{M}} \cdot \mathrm{C}_{\mathrm{HAc}}+\mathrm{k}_{11 \mathrm{M}} \cdot \mathrm{C}_{\mathrm{H}}
\end{aligned}
$$

Equations (27) to (35) present the mass balance of the reactor in batch mode $(\mathrm{F}=0)$ and fed-batch mode $(\mathrm{F} \neq 0)$ regarding the kinetic model (substrate, volatile acids and methane; subscripts "INF" are related to concentration of the compounds in the influent). These equations were used to determine the kinetic parameters of the model.

$\frac{\mathrm{dV}}{\mathrm{dt}}=\mathrm{F}$

$\frac{\mathrm{dC}_{\mathrm{S}}}{\mathrm{dt}}=\frac{\mathrm{F}}{\mathrm{V}} \cdot\left(\mathrm{C}_{\mathrm{SINF}}-\mathrm{C}_{\mathrm{SF}}\right)+\mathrm{r}_{\mathrm{S}}$

$\frac{\mathrm{dC}_{\mathrm{HAc}}}{\mathrm{dt}}=\frac{\mathrm{F}}{\mathrm{V}} \cdot\left(\mathrm{C}_{\mathrm{HAc} \mathrm{INF}}-\mathrm{C}_{\mathrm{HAc}}\right)+\mathrm{r}_{\mathrm{HAc}}$

$\frac{\mathrm{dC}_{\mathrm{HPr}}}{\mathrm{dt}}=\frac{\mathrm{F}}{\mathrm{V}} \cdot\left(\mathrm{C}_{\mathrm{HPr} I N F}-\mathrm{C}_{\mathrm{HPr}}\right)+\mathrm{r}_{\mathrm{HPr}}$

$\frac{\mathrm{dC}_{\mathrm{HBu}}}{\mathrm{dt}}=\frac{\mathrm{F}}{\mathrm{V}} \cdot\left(\mathrm{C}_{\mathrm{HBu} \text { INF }}-\mathrm{C}_{\mathrm{HBu}}\right)+\mathrm{r}_{\mathrm{HBu}}$

$\frac{\mathrm{dC}_{\mathrm{HVa}}}{\mathrm{dt}}=\frac{\mathrm{F}}{\mathrm{V}} \cdot\left(\mathrm{C}_{\mathrm{HVa} I N F}-\mathrm{C}_{\mathrm{HVa}}\right)+\mathrm{r}_{\mathrm{HVa}}$

$\frac{\mathrm{dC}_{\mathrm{EtOH}}}{\mathrm{dt}}=\frac{\mathrm{F}}{\mathrm{V}} \cdot\left(\mathrm{C}_{\mathrm{EtOH} \mathrm{INF}}-\mathrm{C}_{\mathrm{EtOH}}\right)+\mathrm{r}_{\mathrm{EtOH}}$

$\frac{\mathrm{dC}_{\mathrm{H}}}{\mathrm{dt}}=\frac{\mathrm{F}}{\mathrm{V}} \cdot\left(\mathrm{C}_{\mathrm{H} \mathrm{INF}}-\mathrm{C}_{\mathrm{H}}\right)+\mathrm{r}_{\mathrm{H}}$

$\frac{\mathrm{dC}_{\mathrm{M}}}{\mathrm{dt}}=-\frac{\mathrm{F}}{\mathrm{V}} \cdot\left(\mathrm{C}_{\mathrm{M}}\right)+\mathrm{r}_{\mathrm{M}}$

To deal with the differential equation, the Euler numerical integration method (Excel ${ }^{\circledR}$ software) was used and the kinetic parameters were determined by the Solver program (Excel® software), using the 
method of least squares as an optimization (between experimental values and values calculated by the kinetic model).

\section{Estimation of energy production}

To estimate the energy production $\left(\mathrm{E}_{\mathrm{CH} 4}\right)$ and the reactor design on an industrial scale $\left(\mathrm{V}_{\mathrm{R}}\right)_{\mathrm{IND} 3}(\mathrm{~L})$, a method proposed by Albanez et al. (2016) was used. Vinasse production data were obtained from an ethanol plant located in São Paulo, Brazil. The removed volumetric organic load $\left(\mathrm{RVOL}_{\mathrm{MO}}-\mathrm{gCOD}_{\mathrm{L}}{ }^{-1} \cdot \mathrm{d}^{-1}\right)$ and yield of methane generated per consumed load $\left(\mathrm{Y}_{\mathrm{MO}}-\mathrm{mol}_{\mathrm{CH} 4} \cdot \mathrm{gCOD}^{-1}\right)$ were estimated as described in Almeida et al. (2017).

This estimation approach, using industrial data, was carried out only with the objective to demonstrate a preliminary application of the results obtained in this work and to provide information for full-scale use of the investigated technological configuration (AnSBBR). It should be mentioned that detailed studies concerning operational aspects have to be considered to give a precise prediction of the scale-up system. Hewitt et al. (2010) reported a reduction of efficiency in large scale systems for aerobic batch reactors and discussed the importance of impeller type, rotor speed and agitation mode to ensure mass transfer and cell integrity. The dependence between mass transfer, impeller type and consumed power per volume $\left(\mathrm{kW} / \mathrm{m}^{3}\right)$ were also studied by Michelan et al. (2009) using a bench scale anaerobic batch reactor with granular biomass (ASBR), and Novaes et al. (2010) using a pilot scale anaerobic batch reactor with granular biomass (ASBR) and immobilized biomass (AnSBBR).

The methane production $\left(\operatorname{Prod}_{\mathrm{CH} 4}=\mathrm{n}_{\mathrm{CH} 4}\right)$ and combustion energy $\left(\Delta \mathrm{H}_{\mathrm{C}-\mathrm{CH} 4}\right)$ were used to estimate the generated energy $\left(\mathrm{E}_{\mathrm{CH} 4}-\mathrm{MWh}_{\text {.month }}{ }^{-1}\right)$ by means of the daily molar production of methane $\left(\operatorname{Prod}_{\mathrm{CH} 4}-\right.$ mol $\left._{\mathrm{CH} 4} \cdot \mathrm{d}^{-1}\right)$ and the methane enthalpy of combustion $\left(\Delta \mathrm{H}_{\mathrm{C}-\mathrm{CH} 4}=803 \mathrm{~kJ} \mathrm{~mol}^{-1}-\right.$ Perry, 1997) in Equations (36) and (37).

$$
\begin{aligned}
& \operatorname{Prod}_{\mathrm{CH} 4}=\left(\mathrm{V}_{\mathrm{R}}\right)_{\mathrm{IND} 3} \cdot \mathrm{RVOL}_{\mathrm{MO}} \cdot \mathrm{Y}_{\mathrm{MO}} \\
& \mathrm{E}_{\mathrm{CH} 4}=\operatorname{Prod}_{\mathrm{CH} 4} \times \Delta \mathrm{H}_{\mathrm{C}-\mathrm{CH} 4}
\end{aligned}
$$

The energy yield per removed volumetric organic load $\left(\mathrm{YE}_{\mathrm{CH} 4}-\mathrm{kJ} \mathrm{kgCOD}^{-1}\right)$ was calculated by Equation (38) relating the energy power to the removed organic matter.

$\mathrm{YE}_{\mathrm{CH} 4}=\frac{\operatorname{Pr} \mathrm{M} \cdot \Delta \mathrm{H}_{\mathrm{C}-\mathrm{CH} 4}}{\mathrm{RVOL}_{\mathrm{MO}}}$

Through Equation (39) the amount saved per month was calculated by using the bioenergy generated in the system, in which $\mathrm{PWR}_{\mathrm{AnSBBR}}\left(=\mathrm{E}_{\mathrm{CH} 4}-\mathrm{MW}\right)$ corresponds to the energy generated by the AnSBBR $\left(\mathrm{MW}=30 \cdot 24 \cdot \mathrm{MWh}^{\mathrm{month}}{ }^{-1}\right), \$_{\text {un }}$ is the fuel price $\left(\mathrm{US} \$ . \mathrm{m}^{-3}\right)$, ICP is the inferior calorific value and $\rho$ is the density $\left(8,800 \mathrm{kcal} . \mathrm{kg}^{-1}\right.$ and $0.74 \mathrm{~kg} \cdot \mathrm{m}^{-3}$ for natural gas; $10,100 \mathrm{kcal} \cdot \mathrm{kg}^{-1}$ and $840 \mathrm{~kg} \cdot \mathrm{m}^{-3}$ for diesel oil, respectively - ANP, 2015).

$\$_{\text {recovered }}=\frac{\mathrm{PWR}_{\mathrm{AnSBBR}} \cdot \$_{\mathrm{un}}}{\mathrm{ICP} \cdot \rho}$

\section{RESULTS AND DISCUSSION}

\section{Step I (adaptation of biomass)}

Phase 1 comprised assays AT 1, AT 2, AT 3, AT 4 and AT 5, which were operated for seven days each. Table 1 shows the average values of the monitored variables. The stability of the system was confirmed by the results of bicarbonate alkalinity and acids accumulation in the reactor, which were 647

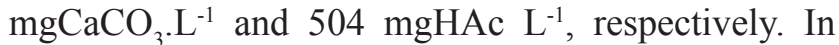
addition, it was observed that, with increasing organic load, alkalinity was generated/consumed and volatile acids accumulated. Removal efficiency as COD and Carbohydrate reached $81 \%$ and $99 \%$, respectively. The results indicated that the biomass was adhered to the inert support and was adapted to the temperature of $55^{\circ} \mathrm{C}$ and influent concentration of $5000{\mathrm{mgCOD} . \mathrm{L}^{-1}}^{-1}$ with molasses-based wastewater.

Phase 2 comprised assays M80/V20, M60/V40, M40/V60, M20/V80 and M0/V100, which were operated for at least seven days each (total of 40 days). The purpose of this phase was to change the substrate used in the reactor start-up, i.e., molasses to vinasse. As shown in Table 1, the total volatile acids concentration in the influent increased (448 to $800 \mathrm{mgHAc} . \mathrm{L}^{-1}$ ) when vinasse was added to the wastewater composition, which led to a drop in the effluent $\mathrm{pH}$ to 6.9. During the first two conditions total volatile acids oscillated due to an imbalance in the microbial community present in the medium. In the following tests the $\mathrm{pH}$ remained near 8.0. Conversely, this condition led to a decrease of approximately $82 \%$ in the TVA concentration in the effluent (504 to $62 \mathrm{mgHAc} . \mathrm{L}^{-1}$ ) and a nearly $150 \%$ increase in the buffer capacity (647 to 1617 $\left.\mathrm{mgCaCO} \cdot \mathrm{L}^{-1}\right)$, proving that vinasse improved system stability, despite its acidity. Consumption of intermediate acids increased during the cycle, mainly acetic and propionic acids (351 to $10 \mathrm{mg} . \mathrm{L}^{-1}$ and 105 to $0 \mathrm{mg} . \mathrm{L}^{-1}$, respectively). Organic matter removal as COD also improved when vinasse was added, achieving an efficiency of $87 \%$ at condition $\mathrm{M} 0 / \mathrm{V} 100$. On the other hand, the carbohydrate removal efficiency was lower (99 to $94 \%$ ) because of the poor biodegradability of vinasse. 
Table 1. Parameters monitored in Step I.

\begin{tabular}{|c|c|c|c|c|c|c|c|c|c|c|}
\hline \multirow{2}{*}{ Parameter } & \multicolumn{5}{|c|}{ Phase 1} & \multicolumn{5}{|c|}{ Phase 2} \\
\hline & AT 1 & AT 2 & AT 3 & AT 4 & AT 5 & M80/V20 & M60/V40 & M40/V60 & M20/V80 & M0/V100 \\
\hline Molasses (\%) & 100 & 100 & 100 & 100 & 100 & 80 & 60 & 40 & 20 & 0 \\
\hline Vinasse $(\%)$ & 0 & 0 & 0 & 0 & 0 & 20 & 40 & 60 & 80 & 100 \\
\hline $\mathrm{T}\left({ }^{\circ} \mathrm{C}\right)$ & 35 & 40 & 45 & 50 & 55 & 55 & 55 & 55 & 55 & 55 \\
\hline $\mathrm{C}_{\mathrm{MO}-\mathrm{inf}}\left(\mathrm{mgCOD} \cdot \mathrm{L}^{-1}\right)$ & 1121 & 2193 & 2959 & 3938 & 5197 & 5069 & 5345 & 5410 & 5060 & 4810 \\
\hline $\mathrm{C}_{\mathrm{MOF}}\left(\mathrm{mgCOD} \cdot \mathrm{L}^{-1}\right)$ & 267 & 431 & 565 & 781 & 1001 & 943 & 661 & 456 & 630 & 632 \\
\hline$\varepsilon_{\mathrm{MOF}}(\%)$ & 76 & 81 & 81 & 80 & 81 & 81 & 88 & 92 & 88 & 87 \\
\hline $\mathrm{C}_{\mathrm{CT} \text {-inf }}\left(\mathrm{mgCarbohydrate} . \mathrm{L}^{-1}\right)$ & 665 & 1314 & 1565 & 2329 & 2957 & 2628 & 1990 & 1544 & 1669 & 976 \\
\hline $\mathrm{C}_{\mathrm{CF}}\left(\mathrm{mgCarbohydrate} . \mathrm{L}^{-1}\right)$ & 14 & 16 & 25 & 31 & 33 & 48 & 39 & 44 & 54 & 62 \\
\hline$\varepsilon_{\mathrm{CF}}(\%)$ & 98 & 99 & 98 & 99 & 99 & 98 & 98 & 97 & 97 & 94 \\
\hline $\mathrm{pH}_{\text {inf }}(\mathrm{u})$ & 8.3 & 8.3 & 8.3 & 8.2 & 8.2 & 7.8 & 7.6 & 7.5 & 7.0 & 6.9 \\
\hline $\mathrm{pH}$ eff $(\mathrm{u})$ & 7.4 & 7.4 & 7.6 & 7.7 & 7.7 & 7.8 & 7.9 & 8.0 & 8.0 & 8.0 \\
\hline $\mathrm{TVA}_{\text {inf }}\left(\operatorname{mgHAc} . \mathrm{L}^{-1}\right)$ & 39 & 72 & 94 & 143 & 151 & 448 & 745 & 852 & 815 & 800 \\
\hline $\mathrm{TVA}_{\mathrm{eff}}\left(\mathrm{mgHAc} . \mathrm{L}^{-1}\right)$ & 140 & 182 & 225 & 339 & 504 & 421 & 106 & 59 & 62 & 76 \\
\hline $\mathrm{BA}_{\text {inf }}\left(\mathrm{mgCaCO}_{3} \cdot \mathrm{L}^{-1}\right)$ & 346 & 692 & 612 & 688 & 958 & 665 & 416 & 435 & 199 & 201 \\
\hline $\mathrm{BA}_{\text {eff }}\left(\mathrm{mgCaCO}_{3} \cdot \mathrm{L}^{-1}\right)$ & 393 & 630 & 704 & 1027 & 647 & 858 & 1350 & 1603 & 1617 & 1605 \\
\hline TS $\inf \left(m g . L^{-1}\right)$ & - & - & - & - & 6307 & 5560 & 5848 & 6138 & 5773 & 5738 \\
\hline $\mathrm{TS}_{\mathrm{eff}}\left(\mathrm{mg} \cdot \mathrm{L}^{-1}\right)$ & - & - & - & - & 3178 & 2485 & 2595 & 2761 & 3128 & 3240 \\
\hline $\mathrm{TSS}_{\text {inf }}\left(\mathrm{mg} \cdot \mathrm{L}^{-1}\right)$ & - & - & - & - & 93 & 97 & 148 & 211 & 169 & 171 \\
\hline $\mathrm{TSS}_{\mathrm{eff}}\left(\mathrm{mg} \cdot \mathrm{L}^{-1}\right)$ & - & - & - & - & 113 & 106 & 130 & 83 & 123 & 89 \\
\hline $\mathrm{VSS}_{\text {inf }}\left(\mathrm{mg} \cdot \mathrm{L}^{-1}\right)$ & - & - & - & - & 54 & 60 & 125 & 163 & 107 & 121 \\
\hline $\mathrm{VSS}_{\text {eff }}\left(\mathrm{mg} \cdot \mathrm{L}^{-1}\right)$ & - & - & - & - & 87 & 89 & 104 & 63 & 74 & 62 \\
\hline
\end{tabular}

As shown in Table 2, addition of vinasse improved the methane fraction $(73 \%)$ in the generated biogas. Up to condition M20/V80 an improvement can be seen in the molar productivity of methane $\left(87 \mathrm{molCH}_{4} \cdot \mathrm{m}^{-3} \cdot \mathrm{d}^{-1}\right)$ and the yield of methane generated by consumed organic matter (14.5 $\left.\mathrm{mmolCH}_{4} \cdot \mathrm{gCOD}^{-1} / 324 \mathrm{NmLCH}_{4} \cdot \mathrm{gCOD}^{-1}\right)$. In contrast, the condition $\mathrm{M} 0 / \mathrm{V} 100$ (vinassebased wastewater) presented a slight decrease in the yield attributed to the vinasse composition and the biomass acclimatization to the substrate (65 $\mathrm{molCH}_{4} \cdot \mathrm{m}^{-3} \cdot \mathrm{d}^{-1}$ and $11.7 \mathrm{mmolCH}_{4} \cdot \mathrm{gCOD}^{-1} /$ $263 \mathrm{NmLCH}_{4} \cdot \mathrm{gCOD}^{-1}$, respectively). Nonetheless, these results indicate that the reactor was stable and had a buffering capacity that was able to prevent accumulation of acids. Therefore, at the end of this step the biomass was adapted to treat the vinassebased wastewater at $55^{\circ} \mathrm{C}$.

Table 2. Performance indicators on Step I.

\begin{tabular}{|c|c|c|c|c|c|c|c|c|c|c|}
\hline \multirow{2}{*}{ Indicator } & \multicolumn{5}{|c|}{ Phase 1} & \multicolumn{5}{|c|}{ Phase 2} \\
\hline & AT 1 & AT 2 & AT 3 & AT 4 & AT 5 & $\mathrm{M80} / \mathrm{V} 20$ & M60/V40 & $\mathrm{M40/V60}$ & $\mathrm{M20} / \mathrm{V80}$ & M0/V100 \\
\hline $\mathrm{M}_{\mathrm{TVS}}(\mathrm{gTVS})$ & 51.1 & 51.1 & 51.1 & 51.1 & 51.1 & 64.3 & 64.3 & 64.3 & 64.3 & 64.3 \\
\hline $\mathrm{C}_{\mathrm{X}}\left(\mathrm{gTVS} . \mathrm{L}^{-1}\right)$ & 21.5 & 21.5 & 21.5 & 21.5 & 21.3 & 26.6 & 27.2 & 27.1 & 27.1 & 27.1 \\
\hline $\operatorname{AVOL}_{M O}\left(g C O D \cdot L^{-1} \cdot d^{-1}\right)$ & 1.0 & 1.0 & 1.0 & 1.0 & 7.05 & 7.04 & 7.22 & 7.35 & 6.90 & 6.52 \\
\hline $\operatorname{RVOL}_{\mathrm{MO}}\left(\mathrm{gCOD} \cdot \mathrm{L}^{-1} \cdot \mathrm{d}^{-1}\right)$ & 1.5 & 3.0 & 4.0 & 5.3 & 5.6 & 5.6 & 6.1 & 6.6 & 6.0 & 5.5 \\
\hline AVOLc $\left(\right.$ gCarbohydrate. $\left.\mathrm{L}^{-1} \cdot \mathrm{d}^{-1}\right)$ & 1.1 & 2.4 & 3.2 & 4.2 & 4.1 & 3.7 & 2.7 & 2.1 & 2.3 & 1.3 \\
\hline RVOLc $\left(\right.$ gCarbohydrate. $\left.\mathrm{L}^{-1} \cdot \mathrm{d}^{-1}\right)$ & 0.9 & 0.9 & 2.1 & 3.2 & 4.0 & 3.6 & 2.6 & 2.0 & 2.2 & 1.2 \\
\hline $\mathrm{V}_{\mathrm{G}}\left(\mathrm{NmL} \cdot\right.$ cycle $\left.^{-1}\right)$ & - & - & - & - & 2278 & 2142 & 2069 & 2141 & 2119 & 1701 \\
\hline $\mathrm{V}_{\mathrm{CH} 4}\left(\mathrm{NmLCH}_{4} \cdot\right.$ cycle $\left.^{-1}\right)$ & - & - & - & - & 1424 & 1406 & 1409 & 1519 & 1534 & 1152 \\
\hline $\mathrm{n}_{\mathrm{CH} 4}\left(\mathrm{molCH}_{4} \cdot \mathrm{d}^{-1}\right)$ & - & - & - & - & 0.19 & 0.19 & 0.19 & 0.20 & 0.21 & 0.15 \\
\hline $\operatorname{MPr}\left(\mathrm{molCH}_{4} \cdot \mathrm{m}^{-3} \cdot \mathrm{d}^{-1}\right)$ & - & - & - & - & 79 & 78 & 80 & 86 & 87 & 65 \\
\hline $\mathrm{SMPr}\left(\mathrm{molCH}_{4} \cdot \mathrm{kgTVS}^{-1} \cdot \mathrm{d}^{-1}\right)$ & - & - & - & - & 3.7 & 2.9 & 2.9 & 3.2 & 3.2 & 2.4 \\
\hline $\operatorname{VPr}\left(\mathrm{NmLCH}_{4} \cdot \mathrm{L}^{-1} \cdot \mathrm{d}^{-1}\right)$ & - & - & - & - & 1779 & 1743 & 1788 & 1918 & 1938 & 1458 \\
\hline $\mathrm{SVPr}\left(\mathrm{NmLCH}_{4} \cdot \mathrm{gTVS}^{-1} \cdot \mathrm{d}^{-1}\right)$ & - & - & - & - & 84 & 66 & 66 & 71 & 72 & 54 \\
\hline $\mathrm{Y}_{\mathrm{MO}}\left(\mathrm{NmLCH}_{4} \cdot \mathrm{gCOD}^{-1}\right)$ & - & - & - & - & 314 & 313 & 292 & 290 & 324 & 263 \\
\hline $\mathrm{X}_{\mathrm{CH} 4}(\%)$ & - & - & - & - & 63 & 66 & 68 & 71 & 72 & 73 \\
\hline $\mathrm{X}_{\mathrm{CO} 2}(\%)$ & - & - & - & - & 36 & 34 & 32 & 29 & 28 & 27 \\
\hline HAc $\left(\mathrm{mmol} . \mathrm{L}^{-1}\right)$ & - & - & - & - & 351 & 196 & 12 & 5 & 9 & 10 \\
\hline $\operatorname{HPr}\left(\mathrm{mmol} . \mathrm{L}^{-1}\right)$ & - & - & - & - & 105 & 188 & 11 & 0 & 0 & 0 \\
\hline $\mathrm{HBu}\left(\mathrm{mmol} . \mathrm{L}^{-1}\right)$ & - & - & - & - & 33 & 33 & 0 & 0 & 0 & 0 \\
\hline $\mathrm{HVa}\left(\mathrm{mmol} . \mathrm{L}^{-1}\right)$ & - & - & - & - & 39 & 35 & 0 & 0 & 0 & 0 \\
\hline
\end{tabular}


Step II (optimization of applied organic load)

Step II comprised assays B5, B6, B7, B8, B9, B10, $\mathrm{B} 12, \mathrm{~B} 14, \mathrm{~B} 17$ and $\mathrm{B} 20$. The reactor was operated for 110 days in batch mode and the vinasse-based wastewater was supplemented with bicarbonate and urea. As shown in Table 3, the increase in influent concentration (with a consequent drop in the inffluent $\mathrm{pH}$ from 8.2 to 5.8) had no influence on the effluent $\mathrm{pH}$ value, which ranged from 8.0 at condition B5 (5000 mgCOD. $\left.\mathrm{L}^{-1}\right)$ to 8.5 at B20 (20000 mgCOD.L $\left.{ }^{-1}\right)$. In fact, even when bicarbonate supplementation was reduced to half in the wastewater from condition B9 $(9000$ $\left.\operatorname{mgCOD} . \mathrm{L}^{-1}\right)$, the $\mathrm{pH}$ exceeded 8.3, i.e., beyond the 6.5 to 8.0 optimum range for thermophilic methanogenic microorganisms (Paulo et al., 2003); behavior similar to that reported in the investigation of Song et al. (2004) in which the $\mathrm{pH}$ remained above 8.0 for thermophilic reactors. Even when TVA accumulation increased with increasing vinasse concentration in the effluent, the system showed improvement in buffer capacity. Hence, in case of an imbalance in TVA concentration the system still remains stable.

Table 3 shows that the organic matter concentration in the form of COD and carbohydrate in the effluent increased as organic load increased. The removal efficiency of organic matter as COD exceeded 80 $\%\left(\varepsilon_{\mathrm{CMO}}\right)$ and as carbohydrate was $93 \%\left(\varepsilon_{\mathrm{C}}\right)$ for the filtered samples at all experimental conditions. The difference between removal efficiencies of COD and carbohydrate can be justified by the presence of poorly biodegradable compounds in the vinasse composition. It should be mentioned that, after the condition changed, both volatile acids consumption and the efficiency of organic matter removal decreased. The increase in solid concentration in the reactor was due to the higher volume of vinasse in the wastewater composition. Despite this fact, there was no large variation in the organic fraction of the solids.

Regarding the performance indicators (Table 4), the biogas volumetric production followed the increase in applied organic load, the maximum volume of biogas (6828 NmL.cycle ${ }^{-1}$ ), volume of methane (5196 $\mathrm{NmLCH}_{4} \cdot$ cycle $^{-1}$ ) and molar yield (305 mmolCH$\left.\cdot \mathrm{m}^{-3} \cdot \mathrm{d}^{-1}\right)$ was achieved at condition B20 (20000 mgCOD.L $\mathrm{L}^{-1}$ ). The mole fraction of methane in the biogas composition was slightly affected during the organic volumetric load increase, ranging from 73 $\%$ at B5 (5000 mgCOD.L $\left.{ }^{-1}\right)$ to $78 \%$ at B20 (20000 mgCOD.L. $\left.L^{-1}\right)$. The yield between generated methane and consumed organic matter was near the theoretical one (15.6 $\left.\mathrm{mmolCH}_{4} \cdot \mathrm{gCOD}^{-1} / 350 \mathrm{NmLCH}_{4} \cdot \mathrm{gCOD}^{-1}\right)$ of condition B8 (8000 mgCOD.L $\mathrm{L}^{-1}$ ). As far as the intermediate compounds are concerned, Table 4 shows there was a predominance of acetic acid, followed by propionic acid at lower concentration. These performance indicators demonstrate the stability of the system and the equilibrium and interaction between the thermophilic microbiological community present in the biomass.

The relationship between the removed and applied organic volumetric loads (Figure 2) indicated that organic matter removal efficiency as COD during Stage II was $79 \%$. The linear behavior indicated that there was no inhibition by the organic load or imbalance in the produced/consumed intermediate compounds. The methane productivity and the removed volumetric

Table 3. Monitored parameters in Steps II and III.

\begin{tabular}{|c|c|c|c|c|c|c|c|c|c|c|c|}
\hline Parameter & B5 & B6 & B7 & B8 & B9 & B10 & B12 & B14 & B17 & B20 & BA20 \\
\hline $\mathrm{C}_{\text {MO-inf }}\left(\mathrm{mgCOD} \cdot \mathrm{L}^{-1}\right)$ & 4810 & 6196 & 7181 & 8259 & 8947 & 10345 & 12270 & 13632 & 17068 & 20084 & 19440 \\
\hline $\mathrm{C}_{\text {MOT-eff }}\left(\mathrm{mgCOD} \cdot \mathrm{L}^{-1}\right)$ & 718 & 890 & 1458 & 1273 & 1534 & 2204 & 2866 & 2792 & 4240 & 4103 & 4391 \\
\hline $\mathrm{C}_{\text {MOF-eff }}\left(\mathrm{mgCOD} \cdot \mathrm{L}^{-1}\right)$ & 632 & 771 & 1285 & 1046 & 1260 & 1863 & 2235 & 2156 & 3386 & 2875 & 3435 \\
\hline$\varepsilon_{\text {МОT }}(\%)$ & 85 & 86 & 80 & 85 & 83 & 79 & 77 & 80 & 75 & 79 & 77 \\
\hline$\varepsilon_{\mathrm{MOF}}(\%)$ & 87 & 88 & 82 & 87 & 86 & 82 & 82 & 84 & 80 & 85 & 82 \\
\hline $\mathrm{C}_{\mathrm{CT} \text {-inf }}\left(\mathrm{mgCarbohydrate} . \mathrm{L}^{-1}\right)$ & 976 & 1173 & 1655 & 1277 & 1646 & 1703 & 2700 & 2623 & 3213 & 4504 & 3292 \\
\hline $\mathrm{C}_{\mathrm{CT} \text {-eff }}\left(\mathrm{mgCarbohydrate} \cdot \mathrm{L}^{-1}\right)$ & 67 & 88 & 110 & 98 & 95 & 116 & 217 & 203 & 310 & 380 & 313 \\
\hline $\mathrm{C}_{\mathrm{CF} \text {-eff }}\left(\mathrm{mgCarbohydrate} \cdot \mathrm{L}^{-1}\right)$ & 62 & 74 & 99 & 76 & 73 & 87 & 158 & 141 & 224 & 263 & 216 \\
\hline$\varepsilon_{\mathrm{CT}}(\%)$ & 93 & 92 & 93 & 92 & 94 & 93 & 92 & 92 & 91 & 91 & 90 \\
\hline$\varepsilon_{\mathrm{CF}}(\%)$ & 94 & 94 & 94 & 94 & 95 & 95 & 94 & 95 & 93 & 94 & 93 \\
\hline $\mathrm{pH}_{\text {inf }}(\mathrm{u})$ & 6.9 & 6.9 & 6.9 & 5.9 & 5.2 & 5.8 & 6.4 & 6.8 & 5.7 & 5.5 & 4.9 \\
\hline $\mathrm{pH} \mathrm{Heff}_{(\mathrm{u})}$ & 8.0 & 8.2 & 8.1 & 8.2 & 8.3 & 8.2 & 8.2 & 8.4 & 8.3 & 8.5 & 8.5 \\
\hline $\mathrm{TVA}_{\text {inf }}\left(\operatorname{mgHAc} . \mathrm{L}^{-1}\right)$ & 800 & 1023 & 1391 & 2000 & 2990 & 2138 & 2522 & 3269 & 4280 & 4884 & 5653 \\
\hline $\mathrm{TVA}_{\mathrm{eff}}\left(\mathrm{mgHAc} . \mathrm{L}^{-1}\right)$ & 76 & 92 & 276 & 172 & 486 & 924 & 713 & 727 & 1284 & 1210 & 1526 \\
\hline $\mathrm{BA}_{\text {inf }}\left(\mathrm{mgCaCO} \mathrm{Ca}_{3} \cdot \mathrm{L}^{-1}\right)$ & 201 & 288 & 57 & 0 & 0 & 66 & 51 & 25 & 0 & 0 & 0 \\
\hline $\mathrm{BA}_{\mathrm{eff}}\left(\mathrm{mgCaCO}_{3} \cdot \mathrm{L}^{-1}\right)$ & 1605 & 1878 & 2139 & 2386 & 2451 & 2284 & 3067 & 3964 & 3570 & 3991 & 3643 \\
\hline $\mathrm{TS}_{\text {inf }}\left(\mathrm{mg} . \mathrm{L}^{-1}\right)$ & 5738 & 6619 & 8713 & 8528 & 9925 & 9868 & 13886 & 15426 & 18964 & 22203 & 18683 \\
\hline $\mathrm{TS}_{\mathrm{eff}}\left(\mathrm{mg} . \mathrm{L}^{-1}\right)$ & 3240 & 3979 & 4763 & 4516 & 4454 & 5631 & 7263 & 7992 & 9476 & 11038 & 9373 \\
\hline $\mathrm{TSS}_{\text {inf }}\left(\mathrm{mg} \cdot \mathrm{L}^{-1}\right)$ & 171 & 257 & 268 & 334 & 120 & 216 & 372 & 354 & 655 & 510 & 807 \\
\hline $\mathrm{TSS}_{\mathrm{eff}}\left(\mathrm{mg} \cdot \mathrm{L}^{-1}\right)$ & 89 & 128 & 155 & 187 & 184 & 290 & 283 & 836 & 524 & 1125 & 792 \\
\hline $\operatorname{SVS}_{\text {inf }}\left(m g \cdot L^{-1}\right)$ & 121 & 189 & 202 & 279 & 84 & 123 & 270 & 245 & 530 & 360 & 642 \\
\hline $\mathrm{SVS}_{\mathrm{eff}}\left(\mathrm{mg} \cdot \mathrm{L}^{-1}\right)$ & 62 & 101 & 119 & 148 & 159 & 204 & 211 & 626 & 367 & 836 & 605 \\
\hline
\end{tabular}


Table 4. Parameter indicators in Step II and III.

\begin{tabular}{|c|c|c|c|c|c|c|c|c|c|c|c|}
\hline Indicator & B5 & B6 & B7 & B8 & B9 & B10 & B12 & B14 & B17 & B20 & BA20 \\
\hline $\operatorname{MTVS}_{\text {TV }}(\mathrm{g})$ & 64.3 & 75.7 & 75.7 & 75.7 & 75.7 & 75.7 & 86.2 & 86.2 & 106.1 & 120.6 & 121 \\
\hline $\mathrm{CX}_{\mathrm{X}}\left(\mathrm{gTVS} . \mathrm{L}^{-1}\right)$ & 27.1 & 31.9 & 32.7 & 32.2 & 31.6 & 31.6 & 37.0 & 37.5 & 46.1 & 52.8 & 53 \\
\hline $\mathrm{C}_{X}{ }^{\prime} \cdot\left(\mathrm{gTVS}\right.$.suporte $\left.{ }^{-1}\right)$ & 1.0 & 1.8 & 1.8 & 1.8 & 1.8 & 1.8 & 1.9 & 1.9 & 2.6 & 2.9 & 2.9 \\
\hline $\operatorname{AVOL}_{\mathrm{MO}}\left(\mathrm{gCOD} \cdot \mathrm{L}^{-1} \cdot \mathrm{d}^{-1}\right)$ & 6.5 & 8.4 & 9.5 & 11.1 & 12.3 & 14.2 & 16.3 & 17.8 & 22.3 & 25.9 & 25 \\
\hline $\operatorname{RVOL}_{M O}\left(\mathrm{gCOD} \cdot \mathrm{L}^{-1} \cdot \mathrm{d}^{-1}\right)$ & 5.5 & 7.2 & 7.5 & 9.4 & 10.2 & 11.2 & 12.5 & 14.1 & 16.7 & 20.6 & 19 \\
\hline $\operatorname{AVOL}_{C}\left(\right.$ gCarbohydrate $\left.\cdot \mathrm{L}^{-1} \cdot \mathrm{d}^{-1}\right)$ & 1.3 & 1.6 & 2.2 & 1.7 & 2.3 & 2.3 & 3.6 & 3.4 & 4.2 & 5.8 & 4.3 \\
\hline 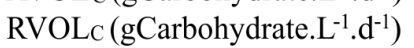 & 1.2 & 1.5 & 2 & 1.6 & 2.1 & 2.2 & 3.3 & 3.2 & 3.8 & 5.3 & 3.8 \\
\hline $\mathrm{V}_{\mathrm{CH} 4}\left(\mathrm{NmLCH}_{4} \cdot\right.$ cycle $\left.^{-1}\right)$ & 1152 & 1819 & 1827 & 2477 & 2891 & 3204 & 3268 & 3967 & 4422 & 5196 & 7391 \\
\hline $\mathrm{n}_{\mathrm{CH} 4}\left(\mathrm{molCH}_{4} \cdot \mathrm{d}^{-1}\right)$ & 0.15 & 0.24 & 0.24 & 0.33 & 0.39 & 0.43 & 0.44 & 0.53 & 0.59 & 0.70 & 0.80 \\
\hline $\operatorname{MPr}\left(\mathrm{molCH}_{4} \cdot \mathrm{m}^{-3} \cdot \mathrm{d}^{-1}\right)$ & 65 & 102 & 106 & 141 & 162 & 179 & 188 & 231 & 257 & 305 & 352 \\
\hline $\mathrm{SMPr}\left(\mathrm{molCH}_{4} \cdot \mathrm{kgTVS}^{-1} \cdot \mathrm{d}^{-1}\right)$ & 2.4 & 3.2 & 3.2 & 4.4 & 5.1 & 5.7 & 5.1 & 6.2 & 5.6 & 5.8 & 6.7 \\
\hline $\operatorname{VPr}\left(\mathrm{NmLCH}_{4} \cdot \mathrm{L}^{-1} \cdot \mathrm{d}^{-1}\right)$ & 1458 & 2296 & 2365 & 3163 & 3622 & 4016 & 4211 & 5175 & 5765 & 6828 & 7888 \\
\hline $\mathrm{SVPr}\left(\mathrm{NmLCH}_{4} \cdot \mathrm{gTVS}^{-1} \cdot \mathrm{d}^{-1}\right)$ & 54 & 72 & 72 & 98 & 115 & 127 & 114 & 138 & 125 & 129 & 149 \\
\hline $\mathrm{Y}_{\mathrm{MO}}\left(\mathrm{mmolCH}_{4} \cdot \mathrm{gCOD}^{-1}\right)$ & 11.7 & 14.2 & 14.0 & 15.1 & 15.9 & 16.1 & 15.1 & 16.3 & 15.4 & 14.8 & 18.1 \\
\hline $\mathrm{Y}_{\mathrm{MO}}\left(\mathrm{NmLCH}_{4} \cdot \mathrm{gCOD}^{-1}\right)$ & 263 & 319 & 315 & 336 & 355 & 359 & 337 & 365 & 345 & 331 & 407 \\
\hline $\mathrm{X}_{\mathrm{CH} 4}(\%)$ & 73 & 76 & 75 & 76 & 77 & 78 & 78 & 77 & 77 & 78 & 77 \\
\hline $\mathrm{X}_{\mathrm{CO} 2}(\%)$ & 27 & 24 & 25 & 24 & 23 & 22 & 22 & 23 & 23 & 22 & 23 \\
\hline HAc $\left(m m o l . L^{-1}\right)$ & 10 & 22 & 31 & 98 & 448 & 541 & 469 & 394 & 420 & 720 & 819 \\
\hline $\operatorname{HPr}\left(\operatorname{mmol} . \mathrm{L}^{-1}\right)$ & 0 & 0 & 0 & 72 & 87 & 99 & 119 & 131 & 152 & 257 & 280 \\
\hline $\mathrm{HBu}\left(\mathrm{mmol} . \mathrm{L}^{-1}\right)$ & 0 & 0 & 0 & 0 & 0 & 0 & 0 & 0 & 0 & 0 & 0 \\
\hline
\end{tabular}

organic load (Figure 2) confirmed that methane productivity was directly related to the organic load increase, i.e., the higher the applied organic load, the greater the availability of organic matter to be converted to methane. The average value during Step II was $15.2 \mathrm{mmolCH}_{4} \cdot \mathrm{gCOD}^{-1}\left(341 \mathrm{NmLCH}_{4} \cdot \mathrm{gCOD}^{-1}\right)$, near the theoretical value of $15.6 \mathrm{mmolCH}_{4} \cdot \mathrm{gCOD}^{-1}$ (350 $\left.\mathrm{NmLCH}_{4} \cdot \mathrm{gCOD}^{-1}\right)$. The linear trend indicates that the applied organic load did not inhibit biogas generation.

The behavior of the reactor shown in Figure 2 allowed us to conclude that the maximum organic load that could be treated by this reactor configuration had not been reached, and reactor stability and performance in relation to the organic matter removal and methane production efficiency was not affected.

Table 5 shows the kinetic model parameters of the metabolic route regarding the change in the applied organic load. The specific parameters are represented by $\mathrm{k}^{\prime}{ }_{10 \mathrm{M}}$ for the acetoclastic route and $\mathrm{k}_{11 \mathrm{M}}$ for the hydrogenotrophic route. It should be mentioned that the kinetic model adequately fitted the experimental data. In the hydrolysis and acidogenesis stage, condition B14 (14000 mgCOD.L $\mathrm{L}^{-1}$ ) presented higher

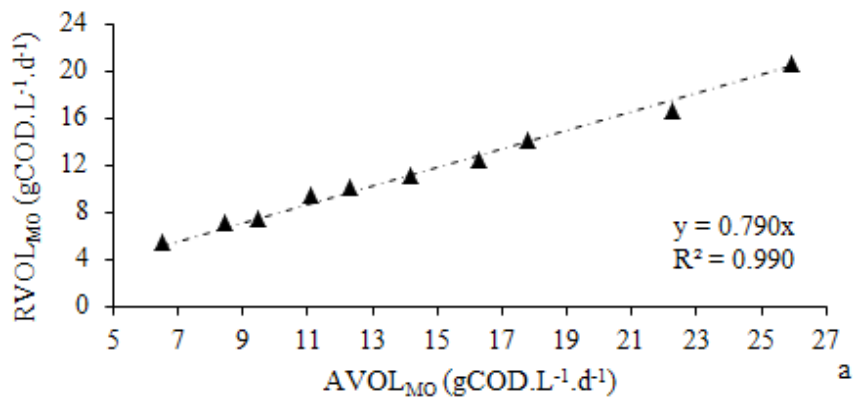

specific rate of organic matter consumption. Regarding the acidogenesis stage, the production rate of acetic acid via ethanol followed the increases in load. It should be mentioned that Condition B5 presented a higher value in the production of organic acids, which is justified by the value of volatile acids obtained during the monitoring. At the methanogenesis stage, methane production via the methanogenic acetoclastic route was predominant for all conditions and methane production via the hydrogenotrophic methanogenic route occurred at conditions $\mathrm{B} 6$ and $\mathrm{B} 7$.

Figure 3 shows the values obtained from the experimental data (markers) and those calculated by the kinetic model (line) referring to substrate consumption (a), production/consumption of intermediate compounds (b) and methane production (c) of the cycle for Condition B20, indicating the good fit between the data calculated by the model and the experimental data.

\section{Step III (feed strategy)}

Table 3 shows the results of the monitoring parameters of step III (BA20 - $20000 \mathrm{mgCOD} . \mathrm{L}^{-1}$ )

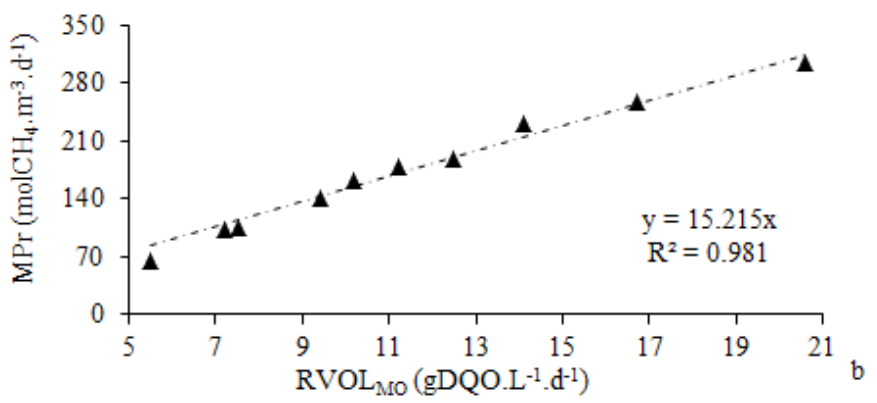

Figure 2. Efficiency of organic matter removal and methane molar productivity. 
Table 5. Kinetic parameters for the conditions of Stages II and III.

\begin{tabular}{|c|c|c|c|c|c|c|c|c|c|c|c|c|}
\hline Step & $\begin{array}{c}\text { Kinetic } \\
\text { Parameters }\end{array}$ & B5 & B6 & B7 & B8 & B9 & B10 & B12 & B14 & B17 & B20 & BA20 \\
\hline \multirow[t]{3}{*}{ Hydrolysis } & & 0.8 & 0.9 & 0.7 & 0.8 & 1.0 & 0.8 & 1.1 & 0.9 & 0.7 & 1.0 & 4.5 \\
\hline & $\mathrm{ks}_{\mathrm{s}}$ & 0.8 & 0.7 & 0.9 & 0.9 & 0.0 & 1.1 & 1.6 & 0.0 & 1.4 & 0.0 & 41.5 \\
\hline & $\mathrm{k}_{2} \mathrm{HPR}$ & 1.2 & 0.8 & 1.3 & 0.9 & 1.4 & 0.9 & 0.9 & 1.0 & 1.0 & 0.6 & 4.8 \\
\hline \multirow[t]{6}{*}{ Acidogenesis } & $\mathrm{k}_{3} \mathrm{HBU}$ & 1.3 & 0.4 & 0.8 & 0.4 & 0.7 & 0.3 & 0.1 & 0.6 & 0.5 & 0.4 & 2.3 \\
\hline & $\mathrm{k}_{4 \mathrm{HVA}}$ & 0.6 & 0.2 & 0.3 & 0.6 & 0.8 & 0.3 & 0.4 & 0.6 & 0.7 & 0.4 & 1.1 \\
\hline & $\mathrm{k}_{5 \mathrm{ETOH}}$ & 0.1 & 0.0 & 0.0 & 0.0 & 0.8 & 0.0 & 0.2 & 1.2 & 2.1 & 1.2 & 1.5 \\
\hline & $\mathrm{kHPr}$ & 0.0 & 0.0 & 0.2 & 0.4 & 1.5 & 0.6 & 1.4 & 1.8 & 2.2 & 1.2 & 8.5 \\
\hline & K9HAC & 1.2 & 0.8 & 1.2 & 0.7 & 0.9 & 0.5 & 0.8 & 1.2 & 1.4 & 0.9 & 3.8 \\
\hline & $\mathrm{k}_{\mathrm{EtOH}}$ & 2.0 & 1.4 & 1.8 & 2.4 & 3.4 & 2.7 & 3.5 & 5.2 & 5.4 & 5.5 & 21.4 \\
\hline \multirow{5}{*}{ Acetogenesis } & $\mathrm{k}_{6 \mathrm{HPR}}$ & 0.7 & 0.4 & 0.6 & 0.3 & 0.1 & 0.1 & 0.1 & 0.1 & 0.1 & 0.0 & 0.1 \\
\hline & $\mathrm{k}_{7 \mathrm{HPR}}$ & 1.5 & 0.2 & 0.4 & 1.6 & 0.0 & 0.1 & 0.3 & 0.0 & 0.0 & 0.0 & 0.0 \\
\hline & $\mathrm{k}_{7 \mathrm{HBU}}$ & 7.0 & 1.0 & 3.0 & 1.4 & 0.6 & 0.2 & 1.3 & 1.3 & 4.5 & 0.4 & 0.6 \\
\hline & $\mathrm{K}_{8 \mathrm{HBU}}$ & 4.2 & 0.1 & 1.0 & 1.1 & 0.0 & 0.1 & 1.3 & 0.8 & 4.6 & 0.0 & 0.0 \\
\hline & k8HVA & 1.0 & 0.4 & 0.6 & 0.7 & 0.7 & 0.1 & 0.4 & 0.6 & 0.7 & 0.5 & 0.3 \\
\hline \multirow{2}{*}{ Methanogenesis } & $\mathrm{K}_{10 \mathrm{M}}$ & 1.3 & 1.6 & 1.4 & 0.8 & 0.7 & 0.6 & 0.8 & 0.8 & 0.9 & 0.7 & 0.0 \\
\hline & $\mathrm{K}_{11 \mathrm{M}}$ & 0.0 & 0.6 & 0.2 & 0.0 & 0.0 & 0.0 & 0.0 & 0.0 & 0.0 & 0.0 & 1.9 \\
\hline
\end{tabular}
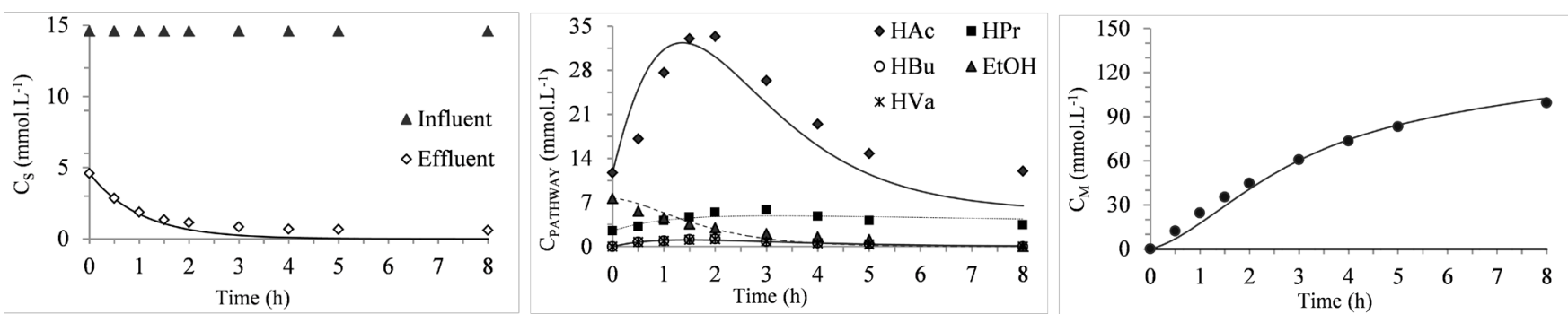

Figure 3. Profiles of organic matter, intermediate compounds and methane at Condition B20.

when the reactor was operated for 25 days in fedbatch mode and the vinasse-based wastewater was supplemented with bicarbonate and urea. The $\mathrm{pH}$ was close to 8.5 , when consumption of bicarbonate alkalinity and accumulation of total volatile acids were higher, due to the fact that production/consumption occurred concurrently with the input of the organic matter, since the feeding time was half the cycle length. Despite this fact, the imposed feeding strategy proved to be able to neutralize the acids produced by the system.

The organic matter removal efficiency (Table 3 ) as COD was $82 \%$ and as carbohydrate exceeded $93 \%$ for filtered samples. In relation to the organic fraction of the solids, there was little variation using this feeding strategy. Regarding the performance of the reactor the results indicated proper functioning of the reactor to treat effluents with high organic matter concentration.

Table 4 presents the results regarding the performance indicators; the fed-batch mode strategy showed superior performance in relation to methane production, in which the molar flow was 0.80 $\mathrm{molCH}_{4} \cdot \mathrm{d}^{-1}$, molar productivity of methane was $352 \mathrm{molCH}_{4} \cdot \mathrm{m}^{-3} \cdot \mathrm{d}^{-1}$ and the volumetric productivity $7888 \mathrm{NmLCH}_{4} \cdot \mathrm{L}^{-1} \cdot \mathrm{d}^{-1}$. In addition, the feed strategy did not affect the biogas composition in terms of methane, which remained near $77 \%$. The molar yield of methane produced by the removed organic matter was $18.1 \mathrm{mmolCH}_{4} \cdot \mathrm{gCOD}^{-1}\left(407 \mathrm{NmLCH}_{4} \cdot \mathrm{gCOD}^{-1}\right)$. This value beyond the theoretical yield was justified by the measurement of organic matter as COD, which contemplates compounds formed during the metabolism (extracellular polymers - mainly produced in the fed-batch assay) that were dissolved due to the thermophilic condition. Hence, at the end of a cycle the effluent containing these compounds increases the COD value and the molar yield of methane produced by the removed organic matter becomes overestimated. However, despite this fact, the results indicate that this feeding strategy had a positive effect on the microorganisms metabolism and stimulated the production of biogas.

Analysis of the kinetic parameters of the metabolic route (Table 4) allowed us to identify that the fed batch condition presented a higher specific rate of organic matter consumption (hydrolysis and acidogenesis), as well as of acetic acid production. In the acetogenesis stage, the priority route for acetic acid production resulted in higher propionic acid and ethanol consumption. The higher organic acids production contributed to acid accumulation in the system. In the methanogenesis stage methane formation was mainly due to the hydrogenotrophic route.

Figure 4 exhibits the values obtained from the experimental data (symbols) and those calculated by the kinetic model (line) referring to the substrate 

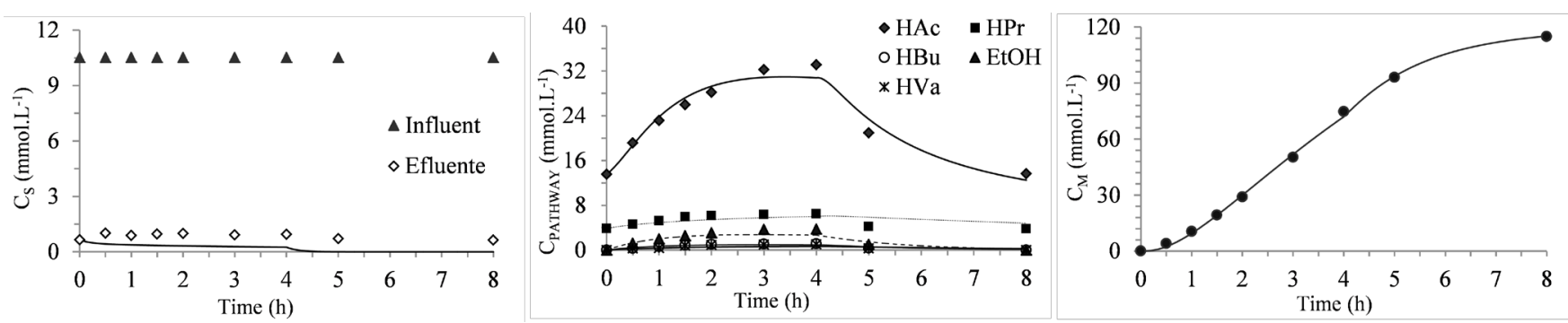

Figure 4. Profiles of organic matter, intermediate compounds and methane in Condition BA20.

consumption (a), production and consumption of intermediate compounds (b) and methane production (c) along the cycle for condition BA20, showing that the data calculated by the kinetic model fitted the experimental data.

\section{Estimation of energy production}

The estimation of energy production (Table 6) was performed considering the condition which presented the best results, i.e., Condition BA20 (fed batch $\left.-20000 \mathrm{mgCOD} . \mathrm{L}^{-1}\right)$. The vinasse production and harvest period were $1.962 \times 10^{6} \mathrm{~m}^{3}$ and 253 days, respectively. An industrial reactor volume of 20,300 $\mathrm{m}^{3}$ was estimated to treat vinasse, and four AnSBBR reactors of $5084 \mathrm{~m}^{3}$ each, working in parallel, were proposed to render the industrial operation feasible.

The estimated power recovered in this process was $30.3 \mathrm{MW}$, i.e, $2.2 \times 10^{4} \mathrm{MWh}$ per month, equivalent to the consumption of $134 \times 10^{3}$ habitants, considering a Brazilian average energy consumption per capita of $163 \mathrm{kWh} . \mathrm{month}^{-1}$ in the first semester of 2017 (ANEEL, 2017). For an alcohol plant using natural gas or diesel oil as fuel in the process, the bioenergy produced in the AnSBBR corresponds to a saving of US\$2,167,000 or US\$2,234,000 per month, respectively. Values for natural gas and diesel oil were considered according to ANP (2017), US\$ $0.752 \mathrm{~m}^{-3}$ and US\$ $1,011 \mathrm{~m}^{-3}$, respectively, and a dollar rate of US\$1.000/R $\$ 3.213$ (BCB, 2017).

Comparing AnSBBR configurations treating vinasse, Albanez et al. (2016) estimated an energy production of $1.3 \times 10^{4} \mathrm{MWh}$ per month, using biogas from an AnSBBR reactor at mesophilic conditions, with an influent concentration of 5000
$\operatorname{mgCOD} . \mathrm{L}^{-1}$, whereas the estimated energy generation at thermophilic conditions for the same influent concentration in our investigation was higher $\left(1.6 \times 10^{4}\right.$ MWh per month). Data reported by Almeida et. al. (2017) allowed us to estimate an energy production from the biogas generated in an AnSBBR reactor at mesophilic condition of $1.8 \times 10^{4} \mathrm{MWh}$ per month for the influent concentration of $10000 \mathrm{mgCOD} . \mathrm{L}^{-1}$. The estimated energy generation for the same influent concentration in our investigation was $2.1 \times 10^{4}$ MWh per month. On analyzing the estimated energy generated from the biogas produced in an AnSBBR reactor treating vinasse, the thermophilic configuration proved to be more efficient. It should be mentioned that technological possibilities for harvesting biogas energy include boilers and turbines, which should be studied to estimate efficiency and economical aspects.

It should be mentioned that the estimation of the energy production and the reactor volume using industrial data was carried out only with the objective to demonstrate a preliminary application of the results obtained in this work and to provide information for full-scale use of the investigated technological configuration (AnSBBR).

\section{Comparative analysis with the literature}

A comparison of the results of this study with investigations found in the literature which dealt with reactors that treat vinasse is shown in Table 7. In the current study, an AnSBBR reactor operated at thermophilic conditions to treat AVOL of $25.9 \mathrm{gCOD} . \mathrm{d}^{-}$ ${ }^{1} \cdot \mathrm{L}^{-1}$ achieved organic matter removal efficiency as COD of $85 \%$ and methane yield produced per removed organic matter of $330 \mathrm{NmLCH}_{4} \cdot \mathrm{gCOD}^{-1}$. The

Table 6. Estimated energy production.

\begin{tabular}{|c|c|c|c|c|c|c|}
\hline Parameters & $\begin{array}{c}\text { B5 } \\
\text { (this work) }\end{array}$ & $\begin{array}{c}\text { B10 } \\
\text { (this work) }\end{array}$ & $\begin{array}{c}\text { B20 } \\
\text { (this work) }\end{array}$ & $\begin{array}{c}\text { BA20 } \\
\text { (this work) }\end{array}$ & $\begin{array}{c}\text { Albanez et al. } \\
(2016)\end{array}$ & $\begin{array}{c}\text { Almeida et al. } \\
(2017)\end{array}$ \\
\hline Temperature $\left({ }^{\circ} \mathrm{C}\right)$ & 55 & 55 & 55 & 55 & 30 & 30 \\
\hline $\mathrm{C}_{\text {MOafl }}\left(\mathrm{mgCOD} \cdot \mathrm{L}^{-1}\right)$ & 4810 & 10345 & 20084 & 19440 & 5000 & 10000 \\
\hline $\mathrm{C}_{\text {MOTeff }}\left(\mathrm{mgCOD} \cdot \mathrm{L}^{-1}\right)$ & 720 & 2204 & 4103 & 4391 & 977 & 261 \\
\hline RVOL (gCOD.L $\left.\mathrm{L}^{-1} \cdot \mathrm{d}^{-1}\right)$ & 5.5 & 11.2 & 20.6 & 19.4 & 4.58 & 9.8 \\
\hline $\mathrm{n}_{\mathrm{CH} 4}\left(\mathrm{molCH}_{4} \cdot \mathrm{d}^{-1}\right)$ & $2.4 \times 10^{6}$ & $3.2 \times 10^{6}$ & $2.7 \times 10^{6}$ & $3.3 \times 10^{6}$ & $1.9 \times 10^{6}$ & $2.7 \times 10^{6}$ \\
\hline $\mathrm{Y}_{\mathrm{MO}}\left(\mathrm{mmolCH}_{4} \cdot \mathrm{gCOD}^{-1}\right)$ & 11.7 & 16.1 & 14.8 & 18.1 & 9.5 & 12.6 \\
\hline $\mathrm{Y}_{\mathrm{MO}}\left(\mathrm{NmLCH}_{4} \cdot \mathrm{gCOD}^{-1}\right)$ & 263 & 359 & 331 & 407 & 213 & 282 \\
\hline YEMO (kJ.kgCOD $\left.{ }^{-1}\right)$ & $9.4 \times 10^{3}$ & $1.3 \times 10^{4}$ & $1.2 \times 10^{4}$ & $1.5 \times 10^{4}$ & $7.6 \times 10^{3}$ & $1.0 \times 10^{4}$ \\
\hline Energy - ECH 4 (MWh.month $\left.{ }^{-1}\right)$ & $1.6 \times 10^{4}$ & $2.1 \times 10^{4}$ & $1.8 \times 10^{4}$ & $2.2 \times 10^{4}$ & $1.3 \times 10^{4}$ & $1.8 \times 10^{4}$ \\
\hline
\end{tabular}


Table 7. Results of studies reported in the literature.

\begin{tabular}{|c|c|c|c|c|c|c|}
\hline Reactor & $\begin{array}{c}\mathbf{t}_{\mathrm{c}}{ }^{1 / H_{H}} \mathbf{H T}^{2} \\
(\mathrm{~h})\end{array}$ & $\begin{array}{c}\mathrm{T} \\
\left({ }^{\circ} \mathrm{C}\right)\end{array}$ & $\begin{array}{c}\text { AVOL } \\
\left(g^{\prime} \text { OD. }^{-1} \cdot d^{-1}\right)\end{array}$ & $\begin{array}{l}\varepsilon_{\text {MOF }} \\
(\%)\end{array}$ & $\begin{array}{c}\text { Volumetric } Y_{M O} \\
\left(\mathrm{NmLCH}_{4} \cdot \mathrm{gCOD}^{-1}\right)\end{array}$ & $\begin{array}{c}\mathrm{VPr} \\
\left(\mathrm{NmLCH}_{4} \cdot \mathbf{L}^{-1} \cdot \mathbf{d}^{-1}\right)\end{array}$ \\
\hline AnSBBR $^{a}$ & $0.2^{1}$ & 55 & 26 & 78 & 331 & 6828 \\
\hline $\mathrm{AnSBBR}^{\mathrm{a}}$ & $4.0^{1}$ & 55 & 25 & 77 & 407 & 7888 \\
\hline $\mathrm{UASB}^{\mathrm{b}}$ & $52.8^{2}$ & 55 & $25-30$ & 72 & 400 & - \\
\hline $\mathrm{UASB}^{\mathrm{c}}$ & $61.2^{2}$ & 55 & 24 & 45 & 290 & - \\
\hline UASB I $^{\mathrm{d}}$ & $34^{2}$ & 55 & 25 & 63 & 306 & 2232 \\
\hline UASB II ${ }^{\mathrm{d}}$ & $23^{2}$ & 55 & 25 & 66 & 316 & 2947 \\
\hline $\mathrm{AnSBBR}^{\mathrm{e}}$ & 0.2 & 55 & 5.0 & 69 & - & - \\
\hline AnSBBR $^{f}$ & 0.2 & 45 & 10 & 46 & 160 & 785 \\
\hline $\mathrm{AnSBBR}^{\mathrm{f}}$ & 0.2 & 30 & 5.2 & 97 & 283 & 1424 \\
\hline AnSBBR $^{\mathrm{f}}$ & 0.2 & 30 & 6.2 & 97 & 301 & 1815 \\
\hline $\mathrm{AnSBBR}^{\mathrm{f}}$ & 0.2 & 30 & 10 & 97 & 281 & 2767 \\
\hline AnSBBR $^{g}$ & 4.0 & 30 & 5.5 & 83 & 212 & 973 \\
\hline
\end{tabular}

Notation: ${ }^{\mathrm{a}}$ This work; ${ }^{\mathrm{b}}$ Silva et al. (1992); ${ }^{\mathrm{c}}$ Harada et al. (1996); ${ }^{\mathrm{d}}$ Ferraz Junior (2016); ${ }^{\mathrm{e}}$ Ribas et al. (2009); ${ }^{\mathrm{f}}$ Almeida et al. (2017); ${ }^{\mathrm{g}}$ Albanez et al. (2016).

results are superior to those reported by Harada et al. (1996), who operated a thermophilic UASB reactor, in which the COD removal efficiency was $40 \%$ and the methane yield $290 \mathrm{NmLCH}_{4} \cdot \mathrm{gCOD}^{-1}$. The lower efficiency might be related to the difference in scale, the vinasse composition and the higher accumulation of propionate with increasing load. The results obtained in the current study were similar to those reported by Silva et al. (1992) who operated a pilot scale thermophilic UASB reactor and achieved $72 \%$ removal efficiency of organic matter as COD and yield of $400 \mathrm{NmLCH}_{4} \cdot \mathrm{gCOD}^{-1}$.

Ferraz Junior et al. (2016) analyzed the behavior of a single-stage thermophilic UASB (I) reactor treating vinasse and a two-stage thermophilic UASB (II) reactor, treating effluent from an acidogenic reactor that also treated vinasse. The results obtained were inferior to those in this work for removal efficiency (I $62.8 \%$ and II - $65.7 \%$ ), volumetric yield of methane (I - $306 \mathrm{NmLCH}_{4} \cdot \mathrm{gCOD}^{-1}$ and II $-316 \mathrm{NmLCH}_{4} \cdot \mathrm{gCOD}^{-}$ $\left.{ }^{1}\right)$ and methane fraction in the biogas (I - $58 \%$ and II - $76 \%$ ).

Ribas et al. (2009) reported a $69 \%$ organic matter removal efficiency as COD in an AnSBBR thermophilic reactor. When the AVOL was increased, higher instability was observed and supplementation of the bicarbonate was needed in the effluent. The lower yield and instability in the thermophilic reactor were attributed to the adaptation of the mesophilic sludge used, as well as to operational difficulties.

Albanez et al. (2016) treated vinasse at $30{ }^{\circ} \mathrm{C}$ in an AnSBBR similar to that used in the present investigation. The results reported were COD removal efficiency of $83 \%$, higher than that reached in the thermophilic condition. However, at the thermophilic condition studied in this work the yield of methane generated per organic matter consumed and the methane productivity were higher.

Almeida et al. (2017) analyzed an AnSBBR similar to the reactor used in the present work, operated at 30
${ }^{\circ} \mathrm{C}$ and $45{ }^{\circ} \mathrm{C}$. They achieved COD removal efficiency of $97 \%$ at mesophilic condition, yield of methane produced per consumed organic load of $281 \mathrm{NmLCH}_{4}$. $\mathrm{gCOD}^{-1}$, volumetric methane production of 2767 $\mathrm{NmLCH}_{4} \cdot \mathrm{L}^{-1} \cdot \mathrm{d}^{-1}$ and methane fraction of $78 \%$ in the biogas composition. At the thermophilic condition of $45{ }^{\circ} \mathrm{C}$ the reactor presented low yield of methane production (160 $\left.\mathrm{NmLCH}_{4} \cdot \mathrm{gCOD}^{-1}\right)$, low methane volumetric production of $785 \mathrm{NmLCH}_{4} \cdot \mathrm{L}^{-1} \cdot \mathrm{d}^{-1}$ and organic matter removal efficiency of $46 \%$. The performance regarding removed organic matter and stability of the AnSBBR used in our study disagrees with that reported by Ribas et al. (2009) and Almeida et al. (2017), achieving better values in relation to the parameters mentioned by the authors. Therefore, the AnSBBR reactor containing immobilized biomass, operated under thermophilic condition, showed a feasible configuration for the treatment of vinasse. Furthermore, in the current literature, this reactor configuration has been increasingly used for the production of methane or hydrogen, as bioenergy can be produced from the treatment of various wastewaters, such as vinasse, whey, domestic sewage, effluent from biodiesel production and other industrial effluents (Bezerra et al., 2011; Oliveira et al., 2009; Rodrigues et al., 2011; Lovato et al., 2012; Albanez et al., 2016; Lima et al., 2016).

\section{CONCLUSIONS}

Methane production from vinasse wastewater by a thermophilic AnSBBR reactor was successfully achieved. Best results were obtained in the fed-batch mode at volumetric organic load of 25 gCOD.L ${ }^{-}$ ${ }^{1} \cdot \mathrm{d}^{-1}$, which led to average COD and carbohydrate removal of $82 \%$ and $93 \%$, respectively, as well as methane productivity, yield and content in biogas of $352 \mathrm{molCH}_{4} \cdot \mathrm{m}^{-3} \cdot \mathrm{d}^{-1}, 18.1 \mathrm{mmolCH}_{4} \cdot \mathrm{gDQO}^{-1}$ (407 $\mathrm{NmLCH}_{4} \cdot \mathrm{gDQO}^{-1}$ ) and $77 \%$, respectively. Fitting a kinetic model to the experimental data revealed 
predominance of acetic acids and showed that methane production occurred primarily via the acetoclastic route.

The reactor showed its energy recovery potential in treating vinasse with high organic matter concentration. Using the results of the laboratory scale reactor, for a real scale treatment plant (vinasse production of $1.962 \times 10^{6} \mathrm{~m}^{3}$ and harvest period of 253 days) four $5084 \mathrm{~m}^{3}$ AnSBBRs working in parallel (industrial reactor volume of $20,300 \mathrm{~m}^{3}$ ) were estimated, resulting in an energy recovery of $2.2 \times 10^{4}$ MWh per month, equivalent to an energy consumption of $134 \times 10^{3}$ inhabitants in Brazil. In an alcohol plant, savings might reach US\$2,167,000 or US\$2,234,000 upon replacing natural gas fuel or diesel oil for the bioenergy produced in the AnSBBR, respectively.

The results obtained in this study proved that the digestion of vinasse in a thermophilic AnSBBR reactor is an efficient technological and environmental compliant alternative for methane production in the treatment of high organic load wastewater.

\section{NOTATION}

AnSBBR Anaerobic Sequencing Batch Biofilm Reactor

ASBR Anaerobic Sequencing Batch Reactor

AVOL Applied volumetric organic load, expressed by COD or Carbohydrate (gCOD. $\mathrm{L}^{-1} \cdot \mathrm{d}^{-1}$ or (gCarbohydrate. $\left.\mathrm{L}^{-1} \cdot \mathrm{d}^{-1}\right)$

BA Bicarbonate alkalinity $\left(\mathrm{mgCaCO}_{3} \cdot \mathrm{L}^{-1}\right)$

$\mathrm{C}_{\text {Cinf }} \quad$ Organic matter concentration in the influent (mgCarbohydrate. $\mathrm{L}^{-1}$ )

$\mathrm{C}_{\mathrm{CF}} \quad$ Filtered organic matter concentration (mgCarbohydrate. $\mathrm{L}^{-1}$ )

COD Chemical oxygen demand (mgCOD. ${ }^{-1}$ )

$\mathrm{C}_{\mathrm{MOinf}} \quad$ Organic matter concentration in the influent (mgCOD.L $L^{-1}$ )

$\mathrm{C}_{\mathrm{MOF}} \quad$ Filtered organic matter concentration (mgCOD.L ${ }^{-1}$ )

$\mathrm{C}_{\mathrm{X}} \quad$ Mass of total volatile solids per volume of liquid medium (gTVS.L ${ }^{-1}$ )

EtOH Ethanol concentration (mg.L $\left.\mathrm{L}^{-1}\right)$

HAc Acetic acid concentration (mg. $\left.\mathrm{L}^{-1}\right)$

$\mathrm{HBu} \quad$ Butyric acid concentration (mg. $\left.\mathrm{L}^{-1}\right)$

$\mathrm{HPr} \quad$ Propionic acid concentration (mg. $\left.\mathrm{L}^{-1}\right)$

HVal Valeric acid concentration (mg. $\mathrm{L}^{-1}$ )

MPr Mol of methane per day and per reactor volume $\left(\mathrm{molCH}_{4} \cdot \mathrm{m}^{-3} \cdot \mathrm{d}^{-1}\right)$

$\mathrm{M}_{\mathrm{TVS}} \quad$ Mass of total volatile solids into the reactor (gTVS)

$\mathrm{n}_{\mathrm{CH} 4} \quad$ Moles of methane produced $\left(\mathrm{molCH}_{4} \cdot \mathrm{d}^{-1}\right)$

$\mathrm{pH} \quad$ Hydrogen ion potential

RVOL Removal volumetric organic load, expressed by COD or Carbohydrate (gCOD.L $\mathrm{L}^{-1} \cdot \mathrm{d}^{-1}$ or $\left(\mathrm{gCarbohydrate} . \mathrm{L}^{-1} \cdot \mathrm{d}^{-1}\right)$
SMPr Moles of methane per day and per reactor TVS $\left(\mathrm{molCH}_{4} \cdot \mathrm{kgTVS}^{-1} \cdot \mathrm{d}^{-1}\right)$

SVPr Volume of methane per day and per reactor TVS $\left(\mathrm{NmLCH}_{4} \cdot \mathrm{gTVS}^{-1} \cdot \mathrm{d}^{-1}\right)$

TS Total solids $\left(\mathrm{mgTS}^{-1} \mathrm{~L}^{-1}\right)$

TSS Total suspended solids (mgTSS.L-1)

TVA Total volatile acids (mgHAc. $\left.\mathrm{L}^{-1}\right)$

VSS Volatile suspended solids (mgVSS.L $\left.\mathrm{L}^{-1}\right)$

$\mathrm{V}_{\mathrm{G}} \quad$ Volume of biogas at STP $\left(\right.$ NmL.cycle $\left.^{-1}\right)$

$\mathrm{V}_{\mathrm{CH} 4}^{\mathrm{G}} \quad$ Volume of methane at STP

$\left(\mathrm{NmLCH}_{4} \cdot\right.$ cycle $\left.^{-1}\right)$

$\mathrm{V}_{\mathrm{R}} \quad$ Volume of liquid into the reactor (L)

$\mathrm{V}_{\mathrm{G}}^{\mathrm{R}} \quad$ Volume of biogas at STP $\left(\right.$ NmL.cycle $\left.{ }^{-1}\right)$

VPr Volume of methane per day and per reactor volume $\left(\mathrm{NmLCH}_{4} \cdot \mathrm{L}^{-1} \cdot \mathrm{d}^{-1}\right)$

$\mathrm{X}_{\mathrm{CH} 4} \quad$ Percentage of methane in biogas (\%)

$\mathrm{X}_{\mathrm{CO} 2} \quad$ Percentage of carbonic gas in biogas (\%)

$\mathrm{Y}_{\mathrm{MO}} \quad$ Molar yield of methane from consumed organic matter $\left(\mathrm{mmolCH}_{4} \mathrm{gCOD}^{-1}\right)$

$\mathrm{Y}_{\text {мо }} \quad$ Volumetric yield of methane from consumed organic matter

$\left(\mathrm{NmLCH}_{4} \mathrm{gCOD}^{-1}\right)$

$\varepsilon_{\mathrm{MOF}} \quad$ Removal efficiency of filtered organic matter $(\%)$

\section{ACKNOWLEDGMENTS}

This study was supported by the São Paulo Research Foundation (FAPESP, \#2015/06.246-7), the National Council for Scientific and Technological Development (CNPq, \#443181/2016-0) and the Coordination for the Improvement of Higher Education Personnel (CAPES). We gratefully acknowledge Dr. Baltus C. Bonse's revision of this paper.

\section{REFERENCES}

Albanez, R., Chiaranda, B.C., Ferreira, R.G., França, A.L.P., Honório, C.D., Rodrigues, J.A.D., Ratusznei, S.M. Biological treatment and environmental compliance of vinasse for methane production in an AnSBBR. Applied Biochemistry and Biotechnology, 178, 21-43 (2016). https://doi. org/10.1007/s12010-015-1856-Z

Almeida, W.A., Ratusznei, S.M., Zaiat, M., Rodrigues, J.A.D. AnSBBR Applied to biomethane production for vinasse treatment: effects of organic loading, feed strategy and temperature. Brazilian Journal of Chemical Engineering, 34, 759-773 (2017). https:// doi.org/10.1590/0104-6632.20170343s20150584

ANEEL, National Electric Energy Agency (2017). Available in: http://www.aneel.gov.br. Accessed in November 2017.

ANP. National Agency for Oil, Natural Gas and Biofuels (2015). Available in: < http://www.anp. gov.br>. Accessed in November 2017. 
ANP. National Agency for Oil, Natural Gas and Biofuels (2017). Available in: < http://www.anp. gov.br>. Accessed in November 2017.

APHA, AWWA Standard Methods for the Examination of Water and Wastewater (1995). WPCF. 19 edition, American Public Health Association, Washington.

Bagley, D.M., Brodkorb, T.S. Modeling microbial kinetics in an anaerobic sequencing batch reactor - model development and experimental validation. WaterEnvironmentResearch, 71, 1320-1332(1999). https:/doi.org/10.2175/106143096X122366

Barros, V.G., Duda, R.M., Oliveira, R.A. Biomethane production from vinasse in upflow anaerobic sludge blanket reactors inoculated with granular sludge. Brazilian Journal of Microbiology, 47, 628-639 (2016). https://doi.org/10.1016/j.bjm.2016.04.021

BCB, Brazilian Central Bank (2017). Available in: < http:/www.bcb.gov.br>. Accessed in November 2017.

Bezerra, R.A., Rodrigues, J.A.D., Ratusznei, S.M., Canto, C.S.A., Zaiat, M. Effect of organic load on the performance and methane production of an AnSBBR treating effluent from biodiesel production. Applied Biochemistry and Biotechnology, 165, 347-368 (2011). https://doi. org/10.1007/s12010-011-9255-6

CONAB, Safra de cana (2017). Avaliable from: http:// www.brasil.gov.br/economia-e-emprego/2016/04/ safra-de-cana-2016-17-cresce-em-producao-earea. Accessed January 07.

Dubois, S.M., Gilles, K.A., Hamilton, J.L., Rebers, P.A., Smith, F. Colorimetric Methods for determination of sugar and related substance. Analytical Chemistry, 228, 13-21 (1956). https:// doi.org/10.1021/ac60111a017

Ferraz Junior, A.D.N., Koyama, M.H., Araújo Junior, M. N., Zaiat, M. Thermophilic anaerobic digestion of raw sugarcane vinasse. Renewable Energy, 89, 245-252 (2016). https://doi.org/10.1016/j. renene.2015.11.064

Gamboa, E.E., Cortes, J.M., Perez, L.B., Maldonado, J.D., Zarate, G.H., Gaviria, L.A. Vinasses: characterization and treatments. Waste Management \& Research, 29, 1235-1250 (2011). https://doi. org/10.1177/0734242X10387313

Harada, H., Uemura, S., Chen, A.C., Jayadevan, J. Anaerobic treatment of recalcitrant distillery wastewater by a thermophilic UASB reactor. Bioresource Technology, 55, 212-221 (1996). https://doi.org/10.1016/0960-8524(96)00003-X

Hewitt, C.J., Nienow, A.W. The scale-up of microbial batch and fed-batch fermentation processes. In: Marin Berovic, M., Enfors, S. (Ed.). Comprehensive Bioprocess Engineering. Ljubljana: University of Ljubljana, 295-320 (2010).
Lima, D.M.F., Inoue, R.K., Rodrigues, J.A.D., Ratusznei, S.M., Zaiat, M. Biohydrogen from cheese whey treatment in an AnSBBR: achieving process stability. Brazilian Journal of Chemical Engineering, 33, 871-883 (2016). https://doi. org/10.1590/0104-6632.20160334s20150314

Lovato, G., Bezerra, R.A., Rodrigues, J.A.D., Ratusznei, S.M., Zaiat, M. Effect of feed strategy on methane production and performance of an AnSBBR treating effluent from biodiesel production. Applied Biochemistry and Biotechnology, 166, 2007-2029 (2012). https://doi.org/10.1007/s12010-012-96276

Lovato, G., Ratusznei, S.M., Rodrigues, J.A.D., Zaiat, M. Co-digestion of whey with glycerin in an AnSBBR for biomethane production. Applied Biochemistry and Biotechnology, 178, 126-143 (2016). https://doi.org/10.1007/s12010-015-18630

Michelan, R., Zimmer, T.R., Rodrigues, J.A.D., Ratusznei, S.M., Moraes, D., Zaiat, M., Foresti, E. Effect of impeller type and mechanical agitation on the mass transfer and power consumption aspects of ASBR operation treating synthetic wastewater. Journal of Environmental Management, 90, 1357-1364 (2009). https://doi.org/10.1016/j. jenvman.2008.08.003

Novaes, L.F., Borges, L.O., Rodrigues, J.A.D., Ratusznei, S.M., Zaiat, M., Foresti, E. Effect of fill time on the performance of pilot-scale ASBR and AnSBBR applied to sanitary wastewater treatment. Applied Biochemistry and Biotechnology, 162, 885-899 (2010). https://doi.org/10.1007/s12010009-8803-9

Oliveira, D.S.; Prinholato, A.C.; Ratusznei, S.M.; Rodrigues, J.A.D.; Zaiat, M.; Foresti, E., (AnSBBR applied to the treatment of wastewater from a personal care industry: effect of organic load and fill time. Journal of Environmental Management, 90, 3070-3081 2009). https://doi.org/10.1016/j. jenvman.2009.04.019

Paulo, P.L., Villa, G., van Lier, J.B., Lettinga, G. The anaerobic conversion of methanol under thermophilic conditions: $\mathrm{pH}$ and bicarbonate dependence. Journal of Bioscience and Bioengineering, 96, 213-218 (2003). https://doi. org/10.1016/S1389-1723(03)80184-6

Perry, R.H., Green, D.W. Perry’s Chemical Engineers' Handbook $\left(70^{\text {th }}\right.$ ed.). New York: McGraw Hill (1997).

Ribas, M.M.F., Chinalia, F., Gianotti, E.P., Pozzi, E., Foresti, E. Microbial succession within an anaerobic sequencing batch biofilm reactor (ASBBR) treating cane vinasse at $55^{\circ} \mathrm{C}$. Brazilian Archives of Biology and Technology, 42, 1027-1036 (2009). https://doi. org/10.1590/S1516-89132009000400028 
Ripley, L.E., Boyle, W.C., Converse, J.C. Improved alkalimetric monitoring for anaerobic digestor of high-strength wastes. Journal of Water Pollution Control Federation, 58, 406-411 (1986).

Rodrigues, J.A.D., Oliveira, R.P., Ratusznei, S.M., Zaiat, M., Foresti, E. AnSBBR applied to a personal care industry wastewater treatment: effects of fill time, volume treated per cycle and organic load. Applied Biochemistry and Biotechnology, 163, 127-142 (2011). https://doi.org/10.1007/s12010010-9022-0

Rodrigues, J.A.D., Pinto, A.G., Ratusznei, S.M., Zaiat, M., Gedraite, R. Enhancement of the performance of an anaerobic sequencing batch reactor treating low strength wastewater through implementation of a variable stirring rate program. Brazilian Journal of Chemical Engineering, 21, 423-434 (2004). https:// doi.org/10.1590/S0104-66322004000300007

Selma, V.C., Cotrim, L.H.B., Rodrigues, J.A.D., Ratusznei, S.M., Zaiat, M., Foresti, E. ASBR applied to the treatment of biodiesel production effluent: effect of organic load and fill time on performance and methane production. Applied Biochemistry and Biotechnology, 162, 23652380 (2010). https://doi.org/10.1007/s12010-0109009-x

Silva, M.E., Furzaro, G., Polegato, A.R. Thermophilic anaerobic digestion of vinasse in pilot plant UASB reactor. Water Science and Technology, 25, 213222 (1992). https://doi.org/10.2166/wst.1992.0153

Silva, R.C., Ratusznei, S.M., Rodrigues, J.A.D., Zaiat, M. Anaerobic treatment of industrial biodiesel wastewater by an ASBR for methane production. Applied Biochemistry and Biotechnology, 170, 105-118 (2013). https://doi.org/10.1007/s12010013-0171-9

Song, Y.C., Kwon, S.J., Woo, J.H. Mesophilic and thermophilic temperature co-phase anaerobic digestion compared with single stage mesophilic and thermophilic digestion of sewage sludge. Water Research, 38, 1653-1662 (2004). https://doi. org/10.1016/j.watres.2003.12.019

Vlissidis, A., Zouboulis, A., Thermophilic anaerobic digestion of alcohol distillery wastewaters. Bioresource Technology, 43, 131-140(1993). https://doi.org/10.1016/0960-8524(93)90172-8

Wilkie, A.C., Riedesel, K.J., Owens, J.M. Stillage characterization and anaerobic treatment of ethanol stillage from conventional and cellulosic feedstock. Biomass and Bioenergy, 19, 63-102 (2000). https:// doi.org/10.1016/S0961-9534(00)00017-9

Zaiat, M., Cabral, A.K.A., Foresti, E. Horizontalflow anaerobic immobilized sludge reactor for wastewater treatment: conception and performance evaluation. Brazilian Journal of Chemical Engineering, 11, 33-42 (1994). 
